\title{
Tibouchina sect. Pleroma (D. Don) Cogn. (Melastomataceae) no estado de São Paulo
}

\author{
PAULO JOSÉ FERNANDES GUIMARÃES ${ }^{1}$ e ANGELA BORGES MARTINS ${ }^{1}$
}

(recebido em 23/05/95; aceito em 28/08/96)

\begin{abstract}
Tibouchina sect. Pleroma (D. Don) Cogn. (Melastomataceae) in São Paulo state). Tibouchina Aubl. (Melastomeae), with about 308 species occupies a central position among neotropical Melastomataceae with capsular fruits. Several of these species are mainly concentrated in the Southeast and West-central Brazil. Tibouchina is distributed in 11 sections. This paper aimed to study the species of Tibouchina sect. Pleroma in the state of São Paulo. The following species are recognized: T. chamissoana Cogn., T. clavata (Pers.) Wurdack, T. estrellensis (Raddi) Cogn., T. grandifolia Cogn., T. granulosa (Desr.) Cogn., T. langsdorffiana (Bonpl.) Baill., T. martialis (Cham.) Cogn., T. riedeliana Cogn., T. serrana P. Guimarães \& A. B. Martins, T. stenocarpa (Schrank et Mart. ex DC.) Cogn., T. ursina (Cham.) Cogn. e T. urvilleana (DC.) Cogn. These species are mainly concentrated on the littoral region of the state. We provide a dichotomus key, species descriptions and illustrations.

RESUMO - (Tibouchina sect. Pleroma (D. Don) Cogn. (Melastomataceae) no estado de São Paulo). Tibouchina Aubl. (Melastomeae), com ca. de 308 espécies, ocupa posição central entre as Melastomataceae neotropicais de fruto capsular. Muitas destas espécies estão especialmente concentradas nas regiões sudeste e centro-oeste do Brasil. O gênero Tibouchina encontra-se dividido em 11 seções. Este trabalho teve como objetivo estudar as espécie de Tibouchina sect. Pleroma no estado de São Paulo. São relacionadas as seguintes espécies: T. chamissoana Cogn., T. clavata (Pers.) Wurdack, T. estrellensis (Raddi) Cogn., T. grandifolia Cogn., T. granulosa (Desr.) Cogn., T. langsdorffiana (Bonpl.) Baill., T. martialis (Cham.) Cogn., T. riedeliana Cogn., T. serrana P. Guimarães \& A. B. Martins, T. stenocarpa (Schrank et Mart. ex DC.) Cogn., T. ursina (Cham.) Cogn. e T. urvilleana (DC.) Cogn. Estas espécies estão distribuidas principalmente na região litorânea do estado. Foi elaborada chave de identificação e são apresentadas descrições, comentários, relação do material examinado e ilustrações.
\end{abstract}

Key words - Tibouchina sect. Pleroma, Melastomataceae, São Paulo state

\section{Introdução}

As Melastomataceae têm sua distribuição quase que exclusivamente nos trópicos, e constituem uma das grandes famílias das angiospermas, com aproximadamente 190 gêneros e cerca de 4800 espécies (Renner 1989a). São especialmente bem representadas nas regiões neotropicais que reúnem dois terços deste total, sendo que nenhum gênero da família existe simultaneamente no Velho e no Novo Mundo.

Os estudos publicados sobre as Melastomataceae brasileiras estão em parte restritos aos limites dos estados e nestes nem sempre envolvendo vários gêneros: Bahia (Harley \& Mayo 1980), Rio de Janeiro (Pereira 1960, 1962, 1966, Baumgratz 1982, 1984), Rio Grande do Sul (Rambo 1958, 1966, Souza 1989), Santa Catarina (Wurdack 1962) e São Paulo (Martins 1991). Algumas revisões genéricas realizadas recentemente incluem Aciotis (Mathies 1981), Bellucia, Loreya e Macairea (Renner 1989b),

1. Departamento de Morfologia e Sistemática Vegetais, Universidade Estadual de Campinas Caixa Postal 6109, 13.081-970 Campinas, SP, Brasil.
Bertolonia (Baumgratz 1987), Cambessedesia (Martins 1984), Marcetia (Martins 1989), Pterogastra (Renner 1994a), Pterolepis (Renner 1994 b) e Rhynchanthera (Renner, 1990).

No estado de São Paulo a família Melastomataceae apresenta ampla distribuição, sendo citada nas descrições de floras regionais e levantamentos fitossociológicos. A distribuição da tribo Microlicieae neste estado foi objeto de estudo recente por Martins (1991).

O gênero Tibouchina (Melastomeae) permanece praticamente sem revisão desde o trabalho de Cogniaux (1891), que estabeleceu para este 11 seções, englobando 195 espécies. As espécies publicadas após esta data aumentam este número em cerca de $50 \%$. Até o momento apenas a seção Lepidotae foi revista por Todzia \& Almeda (1991). O gênero foi também estudado por Pereira (1960) que analisou as espécies do Rio de Janeiro e por Souza (1989) que estudou as do estado do Rio Grande do Sul. Com o objetivo de ampliar o conhecimento das Melastomataceae no estado de São Paulo foram estudadas as espécies do gênero Tibouchina sect. Pleroma. Esta seção foi escolhida devido à ampla distribuição das espécies neste estado, ocupando diferentes tipos de ambientes. 


\section{Resultados}

Tibouchina Aubl., Pl. Guian. 1: 445. 1775.

Arbustos, árvores ou raramente ervas. Ramos quadrangulares a subcilíndricos ou cilíndricos, algumas vezes alados, com indumento variado ou glabrescentes, nós podemos apresentar tricomas alongados. Folhas opostas, raramente verticiladas, pecioladas ou sésseis; lâmina de formato variado, geralmente oblongo-lanceolada, membranácea a cartácea, margem inteira raramente serrulada ou ciliada, freqüentemente com indumento nas duas faces ou subglabra, com 3 a 9 nervuras primárias arqueadas ou subparalelas e nervuras secundárias geralmente reticuladas. Inflorescência em panícula terminal ou axilar, dicásio ou flores isoladas. Brácteas 2, bractéolas 2-6, geralmente presentes, involucrais ou raramente em caliptra, internamente glabras, externamente com indumentos presente. Flores pentâmeras, raramente tetrâmeras, pediceladas ou subsésseis. Hipanto campanulado ou tubuloso, seríceo, estrigoso ou glanduloso. Cálice com tubo muito reduzido ou fendido entre as lacínias; lacínias persistentes ou não, internamente glabras, externamente revestidas por tricomas; pétalas obovadas, de lilás a roxo, magenta, raramente rosa ou branca, ápice truncado ou obtuso, apiculado ou ligeiramente emarginado, margem curtamente glanduloso-ciliada. Estames 10,8 nas flores tetrâmeras, alternadamente dimorfos ou menos freqüentemente subisomorfos; filetes filiformes, com indumento ou glabros; antera linear-subulada, raramente oblonga ou truncada, deiscente por um único poro; conectivo usualmente prolongado abaixo das tecas, em geral bituberculado ventralmente além da inserção dos filetes e com a presença ou não de tricomas, dorsalmente apendiculado. Ovário livre ou parcialmente aderido à base do hipanto, pentalocular, tetralocular nas flores tetrâmeras, com tricomas seríceos raramente glandulares no ápice; estilete arcuado ou sigmoidal, glabro ou piloso, estigma puntiforme. Fruto capsular, revestido pelo hipanto persistente. Sementes numerosas, cocleadas e tuberculadas.

Espécie-tipo - Tibouchina aspera Aubl.

Gênero neotropical especialmente concentrado no sudeste do Brasil estendendo-se desde o México e as Antilhas até o norte da Argentina. Está constituido de aproximadamente 308 espécies, distribuídas em 11 seções das quais Tibouchina sect. Octomeris e Tibouchina sect. Lepidotae não estão representadas no Brasil (Cogniaux 1885).

Várias espécies encontramse em posição duvidosa dentro das seções, devido à artificialidade com que algumas destas foram estabelecidas. As seções Diotanthera, Involucrales, Pleroma e, Simplicicaules não formam grupos homogêneos, constituindo seções artificiais, algumas vezes tendo seus limites sobrepostos. Mas enquanto uma revisão global não for feita, esta classificação de Cogniaux é mantida. As demais seções são aparentemente naturais.

As plantas deste gênero ocorrem em quase todas as regiões do estado, preferencialmente na faixa litorânea, na planície e na vegetação das serras do Mar e Mantiqueira.

Para o estado de São Paulo podemos reconhecer sete seções (tabela 1).

Tibouchina sect. Pleroma (D. Don) Cogn. in Mart., Fl. Bras. 14 (3): 330. 1885.

Tabela 1. Distribuição proporcional das seções de Tibouchina no estado de São Paulo.

Seções de Tibouchina

Tibouchina sect. Diplostegia (D. Don) Triana

Tibouchina sect. Involucrales (Naud.) Cogn.

Tibouchina sect. Pleroma (D. Don) Cogn

Tibouchina sect. Simplicicaules (Naud.) Cogn.

Tibouchina sect. Diotanthera (DC.) Cogn.

Tibouchina sect. Pseudopterolepis Cogn.

Tibouchina sect. Purpurella (Naud.) Cogn. no de espécies representadas em São Paulo / no de espécies relacionadas por Cogniaux (1891) 
Arbustos, subarbustos ou árvores; flores reunidas em panículas multiforas, brácteas e bractéolas não sobrepostas no ápice do botão floral; lacínias do cálice decíduas; anteras longamente atenuados-ubuladas no ápice.

Espécie tipo - Tibouchina heteromalla (D. Don) Cogn.

O caráter utilizado por Cogniaux (1885) para definir a seção Pleroma, flores dispostas em panículas multifloras, demonstrou não ser bem representativo, uma vez que 10 das 45 espécies relacionadas por este autor nesta seção apresentam flores reunidas em dicásios terminais, às vezes também axilares. Da maneira como está delimitada, esta seção parece ser parcialmente artificial. A presença de brácteas e bractéolas não sobrepostas no ápice do botão floral e lacínias caducas são as características que melhor definem Tibouchina sect. Pleroma.

Esta seção está melhor representada nos estados da região sudeste do Brasil. No estado de São Paulo suas espécies foram coletadas em diferentes tipos de vegetação: restinga, mata litorânea de planície, floresta Atlântica, campos de altitude, campos brejosos ou úmidos e cerrado.

Chave de identificação para as espécies de Tibouchina sect. Pleroma no estado de São Paulo.

1 Filetes com tricomas 1-2 mm compr., não glandulares ............................................................. 2

Filetes glabros ou com tricomas $0,3 \mathrm{~mm}$ compr., glandulares ..................................................... 6

2 Folhas curtamente pecioladas a subsésseis, pecíolo $0,2-0,5 \mathrm{~cm}$ compr. .......................................... 3

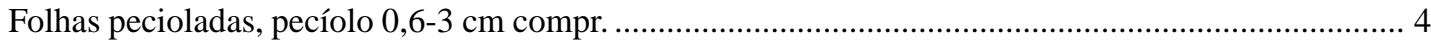

3 Brácteas curtas ou inconspícuas, $0,3-0,5 \mathrm{~cm}$ compr. .................................................. 1. T. martialis

Brácteas longas, 0,8-1 cm compr.

2. T. serrana

4 Face inferior da folha sem tricomas estrelados .................................................. 3. T. stenocarpa

Face inferior da folha com tricomas estrelados .............................................................. 5

5 Face superior da folha bulada, tricomas adpresso-escabros, ramificados na base .......... 4. T. estrellensis

Face superior da folha não bulada, tricomas adpresso-escabros, não ou pouco

ramificados na base

5. T. granulosa

6 Hipanto glanduloso, estilete e filete freqüentemente glabros 7

Hipanto seríceo ou escabro, não glanduloso, estilete e filete freqüentemente pilosos

7 Ápice do ovário com tricomas glandulares curtos, caule não ramificado ou raramente pouco ramificado

6. T. ursina Ápice do ovário com tricomas seríceos longos, caule muito ramificado

8 Hipanto e face superior da folha escabros 7. T. chamissoana Hipanto e face superior da folha seríceos 8. T. riedeliana

9 Conectivo com tricomas glandulares presentes, folhas com pecíolos longos, 3-6, $6 \mathrm{~cm}$ compr 9. T. grandifolia

Conectivo glabro, folhas subsésseis ou com pecíolos curtos, $0,41 \mathrm{~cm}$ compr 10

10 Estilete com tricomas curtos, não glandulares, panículas com eixo até $11 \mathrm{~cm}$ compr., ramos subcilíndricos 10. T. urvilleana

Estilete com tricomas glandulares, panículas com eixo até $39 \mathrm{~cm}$ compr., ramos nitidamente quadrangulares

11 Folhas subsésseis, ramos não alados 11. T. clavata

Folhas pecioladas, pecíolo $0,6-1 \mathrm{~cm}$ compr., ramos subalados 12. T. langsdorffiana

1. Tibouchina martialis (Cham.) Cogn., in Mart., Fl. Bras. 14 (3): 346. 1885.

Lasiandra martialis Cham., Linnaea 9:433. 1834. Figuras 1-7.
Arbusto 0,7-1,5 m alt. Folhas curto-pecioladas; pecíolo 0,2-0,3 cm compr.; lâmina 2,5-4,3 x 0,9-1,6 cm, oblongo-lanceolada, base obtusa, ápice agudo a obtuso, margem inteira e revoluta junto à base, 


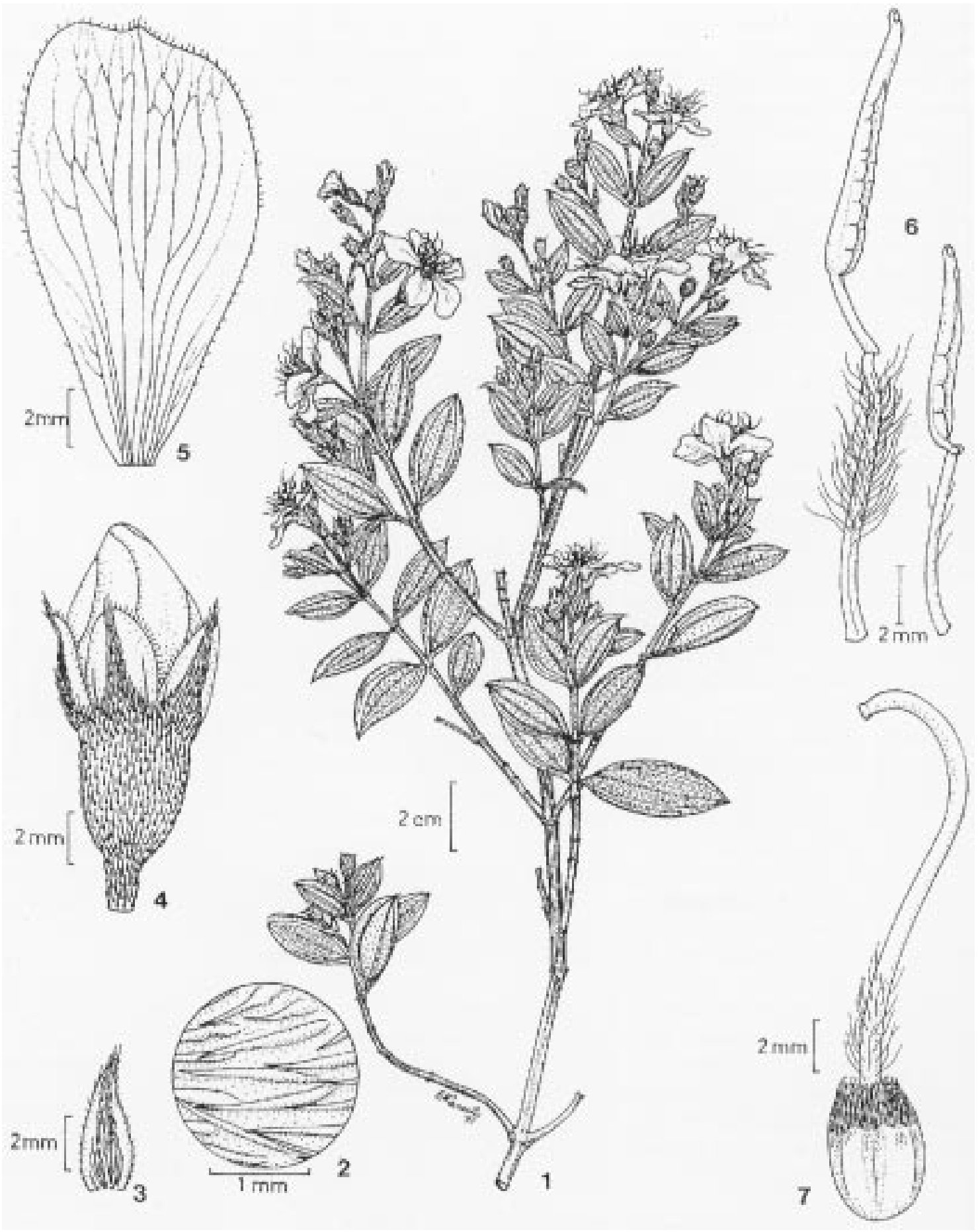

Figuras 1-7. Tibouchina martialis (Cham.) Cogn. (W. Hoenhne s.n. SPF 10.942). 1. Ramo; 2. Tricomas da face superior da folha; 3. Bráctea; 4. Botão floral; 5 Pétala; 6. Estames dos dois ciclos; 7. Gineceu. 
indumento estrigoso na face superior, curto-seríceo na face inferior, nervuras 3 ou 5. Dicásios terminais e axilares, ou flores isoladas axilares, pentâmeras raramente tetrâmeras. Brácteas 3-5 x 1,5-2 mm. Hipanto 0,4-0,6 x 0,3-0,4 cm, escabro. Lacínias 0,4 x 0,2 cm. Pétalas 1,5-1,8 x 0,7-0,9 cm, roxas ou brancas. Estames dimorfos; filetes dos estames menores $0,6-0,7 \mathrm{~cm}$ compr., com poucos tricomas, tecas 0,6-0,75 cm compr., conectivos curtamente prolongados, bituberculados; filetes dos estames maiores 1-1,2 cm compr., tricomas longos nos 2/3 superiores, tecas $0,8-1 \mathrm{~cm}$ compr., conectivos $0,3 \mathrm{~cm}$ compr. prolongados, não bituberculados. Ovário $5 \mathrm{x}$ 3,5 $\mathrm{mm}$, densamente seríceo no ápice; estilete $1,6 \mathrm{~cm}$ compr., com tricomas longos na porção inferior. Cápsula 0,8 x 0,6 cm.

Material selecionado - Caieiras: 06 jan 1942 (fl, fr), W. Hoehne s.n. (SPF 10942, UEC); Campos da Bocaina: 15 abr 1894 (fl), Löfgren \& Edwall [CGGSP] 2431 (SP); Campos do Jordão: 05-20 fev 1937 (fl), P. C. Porto 3164 (RB, NY, F, MO); morro Pedra do Fogo 03 fev 1990 (fl), A. Jouy 1025 (SPF); Cunha: estrada Cunha-Parati, 08 nov 1976 (fl), P. E. Gibbs et al. 3433 (UEC); Ibiúna: 01 dez 1990 (fl), B. Brito s.n. (SPF 67860); Itapetininga: 13 nov 1946 (fl), J. I. de Lima s.n. (RB 58117); Juquiri: entre São Paulo e Jundiaí, 1834 (fl), Riedel 1836 (US); São Francisco dos Campos: Campo e Capão da Boa Vista, 26 dez 1896 (fl), A. Löfgren [CGGSP] 3434 (SP); São Paulo: próximo a Interlagos 14 nov 1952 (fl, fr), W. Hoehne s.n. (SPF 14541, UEC); Serra da Bocaina: 24 abr 1951 (fl), A. C. Brade 20.702 (RB).

T. martialis é um arbusto campestre, melhor representado neste estado nos campos de altitude da região de Campos do Jordão. Da mesma forma, nos demais estados em que foi coletada: Goiás, Mato Grosso, Minas Gerais, Paraná, Rio de Janeiro e no Distrito Federal esta espécie ocorre preferencialmente nas localidades de maior altitude.

Esta espécie é caracterizada por ser um arbusto bem ramificado com a presença de flores reunidas em panículas curtas axilares e terminais, e folhas estrigosas curtamente pecioladas com 3 ou 5 nervuras e brácteas muito reduzidas.

2. Tibouchina serrana P. Guimarães \& A.B.Martins, sp. nov.

Figuras 8-14.
Frutex ca. $1 \mathrm{~m}$. Rami quadrangulati, adpresse strigosi. Petioli 2-5 mm longo; lamina 5,4-7,4 $x$ 1,5-2,7 cm, oblongo-lanceolata, basi obtusa, apice acuto, supra adpresse strigosa, subtus pilis brevibus sparsis sericeis obsita, margine integra, 3-5 nervata. Inflorescentia in paniculis parvis, ca. $10 \mathrm{~cm}$ longis terminalibus axilaribusque. Bracteae duae, 0,8-1 $x$ $0,5 \mathrm{~cm}$, concavae, ovatae, apice acuto, extus centraliter breviter strigosae, ciliatae, bracteolis minores, hypanthium 6-7 x $4 \mathrm{~mm}$, campanulatum, dense strigosum. Calycis tubus brevissimus, lobi 4-6 $x$ 2,5-3 mm, oblongi, apice obtuso ciliato. extus centraliter strigosi, intus glabri post anthesim decidui. Petala 2,2 $\times 1,5 \mathrm{~cm}$, magenta, obovata, apice assymetrice rotundato-truncato, rarius base leviter pilosa et ciliata. Stamina dimorphica, l, l vel $1,3 \mathrm{~cm}$, pilis longissimis, connectivo $1 \mathrm{~mm}$ vel $2,5 \mathrm{~mm}$ prolongato et biturberculato, antherarum thecae 1,1 cm vel 1,3 cm longae. Ovarium $6 \times 4 \mathrm{~mm}$, apice brevissime denseque setuloso, stylo $2,1 \mathrm{~cm}$ glabro vel inferne piloso. Capsulae $6 \mathrm{~mm}$ longae.

Arbusto até $1 \mathrm{~m}$ alt. Folhas curtamente pecioladas; pecíolo 0,2-0,5 cm compr.; lâmina 5,4-7,4 x 1,5-2,7 cm, oblongo-lanceolada, base obtusa, ápice agudo, margem inteira, face superior com indumento adpresso-estrigoso, inferior esparsadamente curto-serícea, nervuras 3 ou 5. Inflorescência em panículas curtas, até $10 \mathrm{~cm}$ compr., terminais e axilares. Brácteas 0,8-1 x $0,5 \mathrm{~cm}$; bractéolas semelhantes, um pouco menores. Hipanto 6-7 x $4 \mathrm{~mm}$, densamente estrigoso, subvelutino. Lacínias 4-6 x 2,5-3 mm. Pétalas 2,2 x $1,5 \mathrm{~cm}$, roxas. Estames dimorfos; filetes com tricomas longos, conectivos bituberculados; filetes dos estames menores ca. 1,1 cm compr., tecas ca. $1,1 \mathrm{~cm}$ compr., conectivo $1 \mathrm{~mm}$ prolongado; filetes dos estames maiores ca. 1,5 cm compr., tecas ca. $1,3 \mathrm{~cm}$ compr., conectivo 2,5 $\mathrm{mm}$ prolongado. Ovário 6 × $4 \mathrm{~mm}$, densamente seríceo no ápice; estilete ca. 2,1 cm compr., glabro ou com tricomas curtos na base. Cápsula 6 x $5 \mathrm{~mm}$.

Typus - Brasil, São Paulo, Brotas, 6 mai 1992 (f,fr), P. Guimarães 114 (Holotipo, UEC; Isotipos, US, F, BM). Paratypi - Minas Gerais: Lafayette: 18-28 mar 1885 (fl), E. A. Vainio s.n. (US 033416). São Paulo: Itapetininga: Campo IV, 5 nov 1887 (fl), Löfgren [CGGSP] 311 (C, R, RB, S, SP); Brotas: fazenda Rochedo, 06 mai 1992 (fl, fr), P. Guimarães 113 (UEC,. SJRP, SP.RB). 
Tibouchina serrana é próxima de T. stenocarpa (Schrank et Mart. ex DC.) Cogn. nos tricomas dos filetes, sendo que desta difere principalmente pelo comprimento do pecíolo. Está relacionada com $T$. martialis (Cham.) Cogn. pelo indumento das folhas e filetes, e comprimento do pecíolo, porém diferindo pelo tamanho das brácteas e tipo de inflorescência. A semelhança com $T$. riedeliana Cogn. é devida ao tamanho das brácteas e indumento das folhas, entretanto a presença de tricomas glandulares curtos

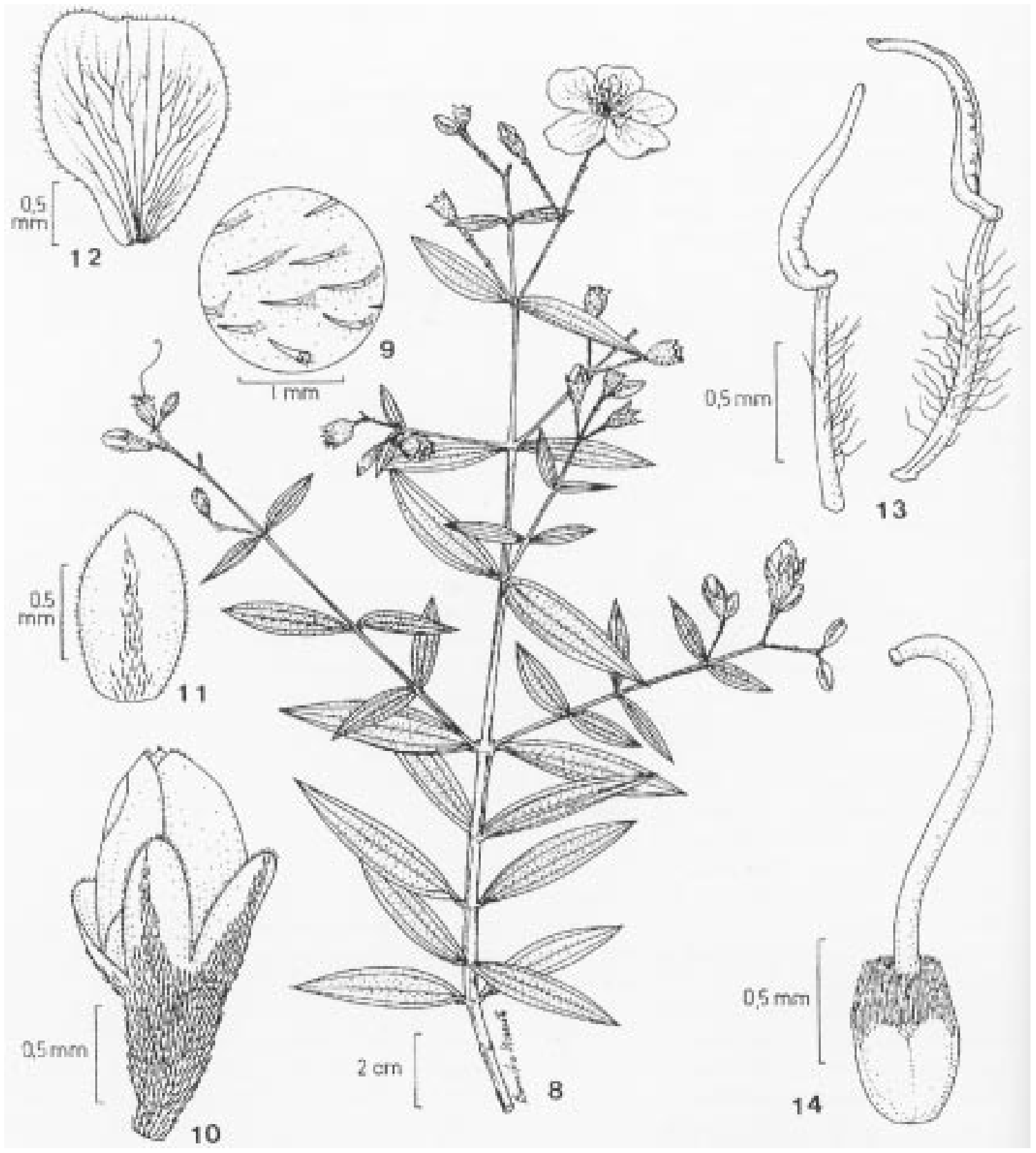

Figuras 8-14. Tibouchina serrana P. Guimarães \& A.B. Martins (P. Guimarães 114 UEC). 8. Ramo; 9. Tricomas da face superior da folha; 10. Botão floral; 11. Bráctea; 12. Pétala; 13. Estames dos dois ciclos; 14. Gineceu. 
nos filetes e o conectivo alongado em $T$. riedeliana separam as duas espécies. Tibouchina serrana distingue-se de $T$. arckermannii Cogn. principalmente pela forma das folhas e pilosidade dos filetes.

Esta espécie, por nós coletada no município de Brotas, região serrana, em morro com afloramento de arenito, foi também coletada no estado de São Paulo em Itapetininga, cujo material (Löefgren [CGGSP] 311) foi incorretamente identificado por Cogniaux (1891) como T. fissinervia (Schrank et Mart. ex DC.) Cogn., que não ocorre em São Paulo. Tibouchina serrana ocorre também no estado de Minas Gerais.

3. Tibouchina stenocarpa (Schrank et Mart. ex DC.) Cogn., in Mart., FI. Bras. 14 (3): 344. 1885.

Lasiandra stenocarpa Schrank et Mart. ex DC., Prodr. 3: 130. 1828.

Figuras 15-20.

Arvoreta ou árvore 1,5-5,0m alt. Ramos sem alas desenvolvidas. Folhas pecioladas; pecíolo 0,6-1,1 cm compr., lâmina 5,5-14 x $25 \mathrm{~cm}$, lanceolado-ovada a oblongo-lanceolada, base obtusa ou raramente cuneada, ápice agudo ou obtuso, margem inteira, face superior longo-estrigosa, inferior serícea com tricomas não estrelados, nervuras 5, as mais externas podendo confluir acima da base. Panículas $9-20,5 \mathrm{~cm}$ compr., terminais ou axilares. Brácteas 1,2-1,3 x 0,5-0,7 cm, bractéolas semelhantes um pouco menores. Hipanto 0,9-1,2 x 0,4-0,6 cm, velutino. Lacínias 0,6 x 0,3 cm. Pétalas 1,8-2,8 x 0,7-1,7 cm, roxas, lilases ou raramente róseas. Estames dimorfos; filetes densamente cobertos por tricomas longos; filetes dos estames menores 0,7-1,2 cm compr., tecas 1-1,2 cm compr., conectivo 0,6-1 $\mathrm{mm}$ prolongado, não bituberculado; filetes dos estames maiores 1,5-1,9 cm compr., tecas $1,3 \mathrm{~cm}$ compr., conectivo 2,4-4 $\mathrm{mm}$ prolongado, bituberculado. Ovário 0,8-0,9 x 0,4 cm, densamente seríceo no ápice; estilete 2-2,2 cm compr., glabro ou raramente piloso. Cápsula 1,2-1,5 cm x 0,7-0,8 cm.

Material Selecionado - Angatuba: floresta de

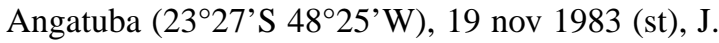
A. Ratter \& G. C. G. Argent 4902 (UEC); Araçoiaba da Serra: km 132 rod. São Paulo-Curitiba, 21 jan
1964 (fl), O. Handro 1085 (SP); Araraquara: Campo lageado 14 abr 1897 (fl), Löfgren [CGGSP] 4313 (SP); Avaré: a $37 \mathrm{Km}$ de Avaré, rodovia Avaré-São Manoel 15 mar 1967 (fl), J. Mattos \& N. Mattos s.n. (UEC 32949); Botucatu: Rubião Junior 16 fev 1920 (fl), G. Gerhrt s.n. (SP 3651); Brotas: fazenda Rochedo 06 mai 1992 (fl), P. Guimarães 115 (UEC); Buri: fazenda Ipuaçu 17 jul 1983 (fl), W. M. Ferreira 14781 (UEC); Butirizal: em acesso na rodovia $14 \mathrm{abr}$ 1981 (fl, fr), H. F. Leitão Filho et al. 12492 (UEC); Caieiras: 17 mar 1947 (fl), W. Hoehne s.n. (SPF 11843, UEC); Campinas: 10 mai 1905 (fl), A. Heiner 480 (MO); Corumbatai: 08 mar 1985 (fl), M.J.O. Campos 85 (UEC); Estação Ressaca: 10 mar 1902 (fl), Löfgren s.n. (SP 12039); Guarei: Sarandi, 2320'S 48¹4'W 21 fev 1981 (fl), Cerantola \& Barbosa 58 (UEC); Indaiatuba: 29 mar 1939 (fl), A. P. Viegas \& J. Kiehl s.n. (IAC 3892, NY); Itapira: 12 mai 1927 (fl), F. C. Hoehne s.n. (SP 20261); Itirapina: 01 abr 1913 (fl), Toledo 577 (RB); Itu: s.d. (fl) A. Russe1 313 (SP); Jundiai: 14 mar 1915 (fl), A. C. Brade s.n. (SP 5948); Limeira: abr 1943 (fl), Kuhlmann s.n.(SP 48230); Matão: 13 fev 1950 (fl) J. Correa 425 (RB); Mogi Guaçu: Fazenda Campininha 27 jan 1992 (fl), P. Guimarães 107 (UEC); Mogi Mirim: horto florestal 15 jan 1979 (fl), D. V. Toledo Filho 10700 (UEC); Piracicaba: Campos de Piracicaba 24 fev 1886 (fl), A. Glaziou s.n. (F 539344); Pirassununga: 12 mar 1952 (fl) B. Pickel s.n. (SPF 65862); Rancharia: 14 fev 1997 (fl), G. Hatschbach 23507 (NY, C); Santo Antônio de Posse: fazenda Hollambra 25 fev 1976 (fl, fr), G. J. Shepherd \& P. F. Gibbs 1271 (UEC); São Carlos: rodovia W. Luiz km 222, entrada para Analândia 28 mar 1962 (fl), M. Labouriau 24 (SP); São Paulo: av. Paulista s.d. ( fl), Usteri 9 (SP 14339); São Simão: 20 mai 1941 (fl), A. S. Lima s.n. (IAC 6275); Tietê: 23 nov 1968 (fr) C. Aranha 125 (IAC); Três Barras: Cafelândia São Paulo 10 set 1938 (fr), G. Hashimoto s.n. (SP 40443).

A ocorrência de T. stenocarpa no estado de São Paulo está relacionada com a região de domínio do cerrado. Apresenta ampla distribuição, em São Paulo e no Brasil ocorrendo na Bahia, Distrito Federal, Goiás, Mato Grosso, Minas Gerais, Pará, Rio de Janeiro e Rondônia extendendo-se ao Paraguai e Bolívia. As coletas realizadas por Martius na Bahia (Cogniaux 1885), em ambiente rupestre, das quais faz parte o material tipo desta espécie, 


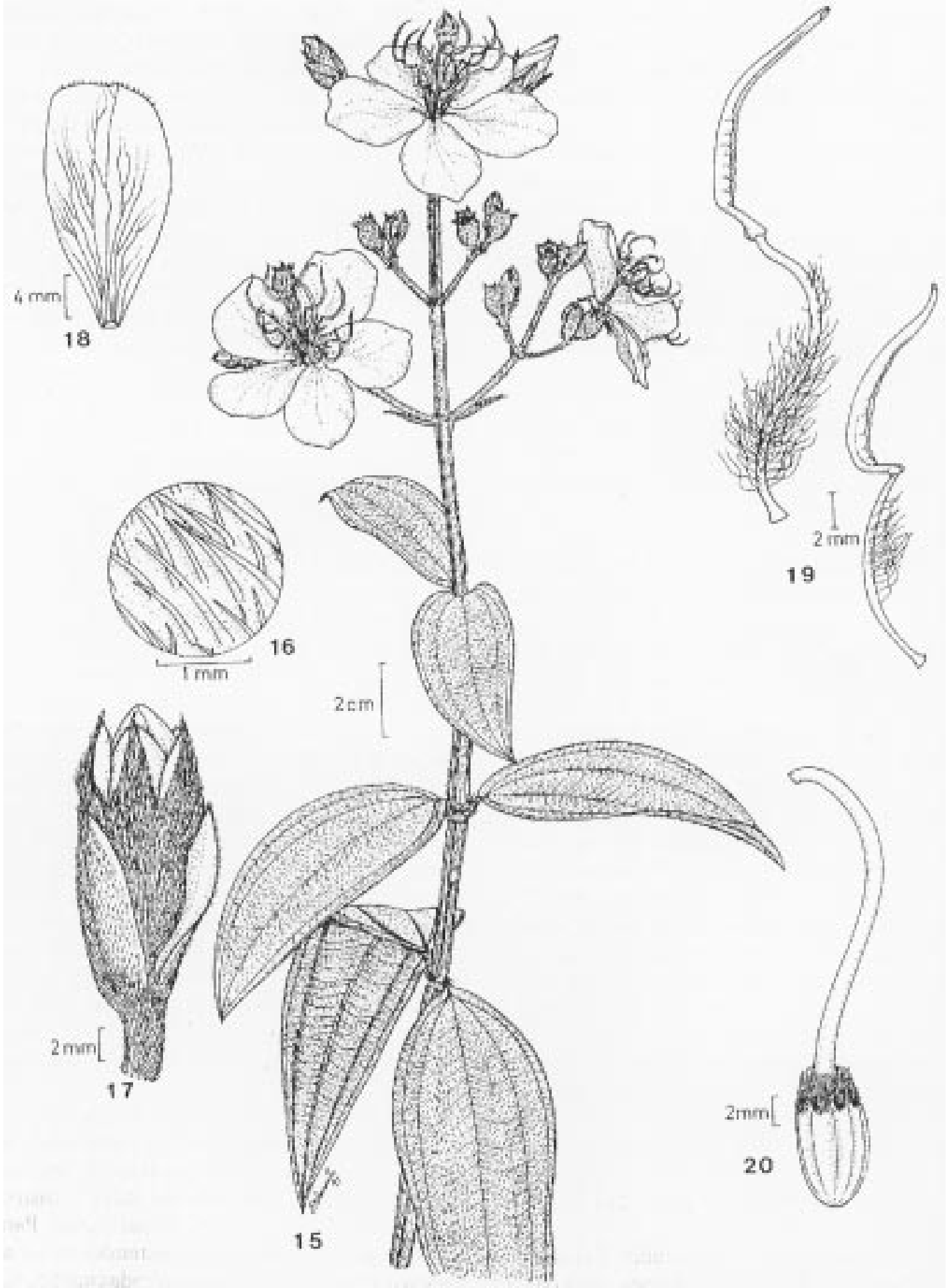

Figuras 15-20. Tibouchina stenocarpa (Schrank et Mart. ex DC.) Cogn. (Cenrantola \& Barbosa 58). 15. Ramo; 16. Tricomas da face superior da folha; 17. Botão floral; 18. Pétala; 19. Estames dos dois ciclos; 20 Gineceu. 
constituem talvez o extremo norte de distribuição de T. stenocarpa.

Esta espécie pode ser reconhecida pela presença de tricomas longos, algumas vezes estrigosos, na face superior da folha (figura 16) e por apresentar apenas tricomas seríceos na face inferior.

Tibouchina stenocarpa é estreitamente relacionada com T. fissinervia e com T. granulosa. Estas diferem de T. stenocarpa pela presença de tricomas estrelados na face inferior da folha, sendo que a presença de ramo alado separa $T$. granulosa das outras duas.

4. Tibouchina estrellensis (Raddi) Cogn., in Mart., Fl. Bras. 14 (3): 342. 1885.

Rhexia estrellensis Raddi, Atti Soc. Ital. Sc. 18 (2): 388. 1820.

Figuras 21-27.

Árvore até $10 \mathrm{~m}$ alt. Ramos subalados até alados. Folhas pecioladas; pecíolo $1-3 \mathrm{~cm}$ compr.; lâmina 11,5-16,2 x 3,5-6,2 cm, 1anceolado-ovada, base obtusa a arredondada ou raramente atenuada, ápice agudo, margem inteira, face superior bulado-escabra, tricomas adpresso-ramificados na base, face inferior foveolada com tricomas estrelados na base, nervuras 5 , podendo as mais externas confluirem acima da base. Inflorescência em panícula 11,5-28 cm compr., terminal. Brácteas $1,6 \times 0,9 \mathrm{~cm}$. Hipanto $0,9 \times 0,4 \mathrm{~cm}$, densamente estrigoso. Lacínias $0,5 \times 0,4 \mathrm{~cm}$. Pétalas 2,5-3,1 x 1,6-1,8 cm, roxas, assimétricas. Estames dimorfos; filetes com tricomas longos, conectivo bituberculado, filetes dos estames menores ca. $1,1 \mathrm{~cm}$ compr., tecas 1,2-1,3 cm compr., conectivos 0,4-0,6 $\mathrm{mm}$ prolongados; filetes dos estames maiores 1,3-1,4 cm compr., tecas 1,3-1,4 cm compr., conectivos 1-1,5 mm prolongados. Ovário 0,9 x $0,4 \mathrm{~cm}$, densamente seríceo no ápice; estilete $2,6 \mathrm{~cm}$ compr., piloso na metade inferior. Cápsula $0,7-1 \times 0,5-0,6 \mathrm{~cm}$.

Material Selecionado - Campinas: 09 fev 1949 (fl), Santoro \& Pacheco s.n. (SP 69 628); Campos do Jordão: Parque Estadual, 14 mai 1986 (fl, fr), M. J. Rubim 405 (SP); Mogi das Cruzes: entre Birituba Mirim e Casa Grande, 30 abr 1958 (fl, fr), O. Handro 772 (SPF, UEC, SP, US, C); Paraibuna: rodovia Paraibuna a Caraguatatuba, 30 mar 1960 (fl), B. Costa s.n. (SP 202196); Pinhal: na encruzilhada para Campos do Jordão, 23 abr 1974 (fl, fr), J. Mattos
15839 (SP); Salesópolis: Casa Grande, 14 mar 1958 (fl), M. Kuhlmann 4330 (US); Serra da Mantiqueira 23 abr 1939 (fl), M. Kuhlmann \& A. Gehrt s.n. (SP 40265); Ubatuba: Picinguaba, trilha do morro do Corsário,12 mar 1992 (fl), R. Romero 459 (UEC); sem localização precisa: s.d. (fl), A. Gtaziow 15989(c).

Tibouchina estrellensis ocorre na Mata Atlântica do estado de São Paulo, até o Espírito Santo, ocorrendo também em Minas Gerais.

Esta espécie pode ser reconhecida pela superfície foliar bulado-escabra, com os tricomas adpresso-ramificados na base, na face superior (figura 22), e na face inferior foveolada com a presença de tricomas estrelados na base.

Segundo Cogniaux (1885), Tibouchina scrobiculata Cogn., é uma espécie próxima, e provavelvente é um nome supérfluo para $T$. estrellensis, pois o carácter distintivo, presença de alas nos ramos, ocorre em ambas espécies.

5. Tibouchina granulosa (Desr.) Cogn., in Mart., Fl. Bras. 14 (3): 332. 1885.

Melastoma granulosa Desr., in Lam., Encycl. méth. Bot. 4 (1). 44.1797.

Figuras 28-33.

Árvore até $6 \mathrm{~m}$ alt. Ramos alados. Folhas pecioladas; pecíolo 1-2,2 cm compr.; lâmina 10,5-16,4 x 2,8-5,2 cm, oblongo-lanceolada, base obtusa, ápice agudo, margem inteira, face superior adpresso-escabra, inferior com tricomas estrelados na base, nervuras 5, as mais externas confluindo acima da base. Panícula 12,5-18 cm compr., terminal ou axilar. Brácteas 1,2-1,5 cm x 1-1,3 cm, bractéolas semelhantes, um pouco menores. Hipanto 0,7-1,1 x 0,5-0,6 cm, seríceo. Lacínias 0,8-0,9 x 0,4-0,5 cm. Pétalas 3-3,3 x 2,2-2,7 cm, roxas ou róseas. Estames pouco dimorfos; filetes com tricomas longos na metade superior, filetes dos estames menores 16-17 mm compr., tecas 13-14 mm compr., conectivo 1-1,3 mm prolongado; filetes dos estames maiores $13-15 \mathrm{~mm}$ compr., tecas $9-12 \mathrm{~mm}$ compr., conectivo 2-2,5 $\mathrm{mm}$ prolongados. Ovário $8 \times 4 \mathrm{~mm}$, densamente seríceo no ápice; estilete $2,2-2,5 \mathrm{~cm}$ compr., glabro. Cápsula 0,8 x 0,6 cm.

Material Examinado - Estrada que liga os municípios de Guaratinguetá a Cunha, em capoeira remanescente, 11 mar 1988 (fl, fr), C. H. B. Monteiro s.n. (SP 224462). 


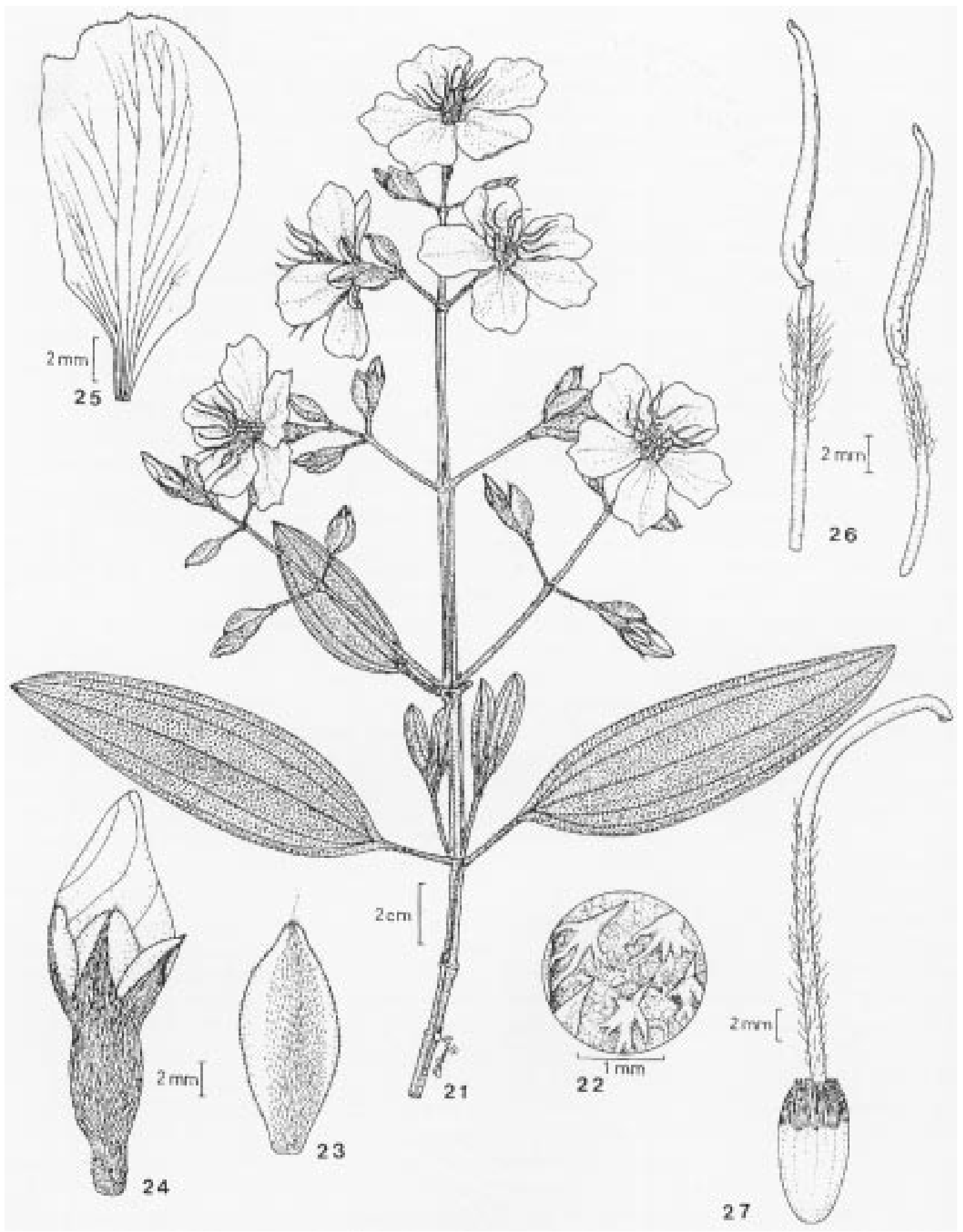

Figuras 21-27. Tibouchina estrellensis (Raddi) Cogn. (Glaziou 15.989). 21. Ramo; 22. Tricomas da face superior da folha; 23. Bractéola; 24. Botão floral; 25. Pétala; 26. Estames dos dois ciclos; 27. Gineceu. 


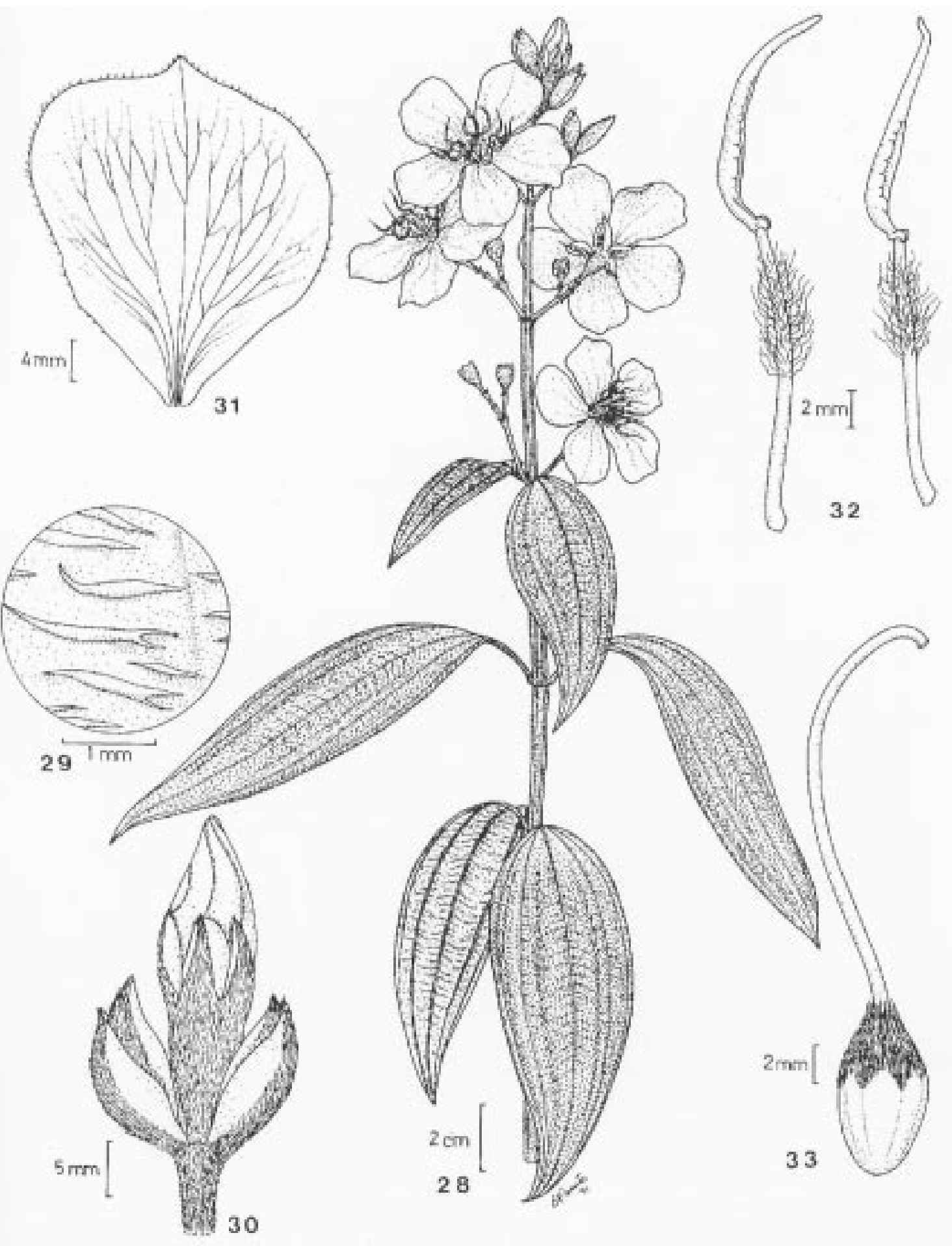

Figuras 28-33. Tibouchina granulosa (Desr.) Cogn. (Monteiro s.n. SP 22.4462). 28. Ramo; 29. Tricomas da face superior da folha; 30. Botão floral; 31. Pétala; 32. Estames dos dois ciclos; 33. Gineceu. 
T. granulosa é bem representada no estado do Rio de Janeiro sendo que o exemplar coletado em São Paulo pertence a uma localidade próxima à divisa destes estados, onde faz parte da vegetação da Mata Atlântica. Outras coletas no estado de São Paulo são mencionadas por Cogniaux (1885, 1891), porém não localizamos estes materiais. Segundo este autor, $T$. granulosa pode ser encontrada ainda nos estados da Bahia, Pará e Minas Gerais. Esta espécie é conhecida popularmente como quaresmeira, sendo bastante utilizada na arborização de ruas e praças.

Pode ser reconhecida pela presença de tricomas adpresso-escabros na face superior da folha (figura 29) e tricomas estrelados na base na face inferior e pela presença de ramo alado.

T. granulosa relaciona-se com T. estrellensis com a qual é confundida. As diferenças estão na superfície foliar bulada na face superior, com tricomas estrigosos adpresso-ramificados na base e foveolada na face inferior em T. estrellensis. Embora ambas sejam referidas para o estado do Rio de Janeiro, T. estrellensis apresenta uma distribuição mais ampla, ocorrendo também nos estados de São Paulo, Minas Gerais e Espírito Santo.

6. Tibouchina ursina(Cham.) Cogn., in Mart., Fl. Bras. 14 (3): 351.1885.

Lasiandra ursina Cham., Linnaea 9: 443. 1834.

Figuras 34-39.

Subarbusto 0,5-0,8 m alt., caule simples, raramente ramificado. Ramo híspido-glanduloso. Folhas sésseis, lâmina 5,6-8,5 x 3-5,2 cm, cordiforme, base cordada, ápice agudo, margem inteira a ligeramente serrilhada, serícea em ambas as faces, nervuras 7-9. Panícula 20-23 cm compr., terminal. Brácteas 1,6-1,8 x 0,7-0,8cm, bractéolas semelhantes um pouco menores. Hipanto 0,8-1,2 x 0,5-0,6 cm, seríceo. Lacínias 0,9-1,2 x 0,3-0,4 cm. Pétalas 2,1 x 1,4 cm, roxas. Estames dimorfos; filetes glabros, eventualmente com tricomas glândulares na porção inferior, conectivos com apêndices bituberculados, filetes dos estames menores ca. 0,9 cm compr., tecas ca. lcm compr., conectivos 1,2 $\mathrm{mm}$ prolongados; filetes dos estames maiores ca. 1,1 cm compr., tecas ca. 1,2 cm compr., conectivos $2 \mathrm{~mm}$ prolongados. Ovário 1,2 x 0,6 cm, ápice fendido, tricomas glandulares curtos; estilete ca. 2,1 cm compr., glabro, raramente glanduloso. Cápsula 1,2 x 0,6 cm.
Material Examinado Selecionado - Campos da Bocaina: Invernada Pinhal, 30 mar 1894 (fl), Löfgren [CGGSP] 2328 (SP); Campos do Jordão: 05 fev 1937 (fl), P. C. Porto 3166 (RB); São José dos Campos: 28 mar 1962 (fl), I. Mimura 337 (NY, UB); São Paulo: Jabaquara, 01 mar 1915 (fl, fr), A. C. Brade 7426 (SP); inter Vila Ema et São Bernardo, 12 jan 1932 (fl), A.C. Brade 12292 (RB); Itaim, 11 jan 1939 (fl, fr), F. C. Hoehne s.n. (SP 39986); Campo Congonhas, 29 jan 1942 (fl,fr), W. Hoehne s.n. (SPF 10996, NY).

Tibouchina ursina foi coletada em ambiente campestre, algumas vezes brejoso. Além do estado de São Paulo ocorre também em Minas Gerais, Paraná e Santa Catarina.

Esta espécie é facilmente reconhecida pelo seu hábito subarbustivo, pouco ramificado, indumento seríceo que reveste diversas partes da planta e folhas cordiformes.

Tibouchina ursina é relacionada com $T$. gracilis (Bonpl.) Cogn., pertencente à seção Simplicicaules, pelo hábito, pilosidade e inflorescência. As diferenças entre as duas estão na forma da folha, tamanho das brácteas e caducidade das lacínias.

A presença de tricomas glandulares curtos na porção superior do ovário foi observada apenas nesta espécie.

7. Tibouchina chamissoana Cogn., in Mart., Fl. Bras. 14 (3): 349. 1885.

Figuras 40-46.

Subarbusto até $1 \mathrm{~m}$ alt. Ramos com tricomas glandulares. Folhas pecioladas, pecíolo 0,2-0,6 cm compr., lâmina 2,5-4(6) x $0,7-1,5(2,2) \mathrm{cm}$, lanceolado-ovada, base obtusa a cordada, ápice agudo, margem inteira, curtamente ciliada, face superior piloso-glandulosa, inferior tomentos-ovilosa, nervuras 5, recobertas por tricomas glândulares. Inflorescência em dicásios terminais (3-7 flores) ou axilares (3 flores), ou flores isoladas axilares. Brácteas $0,6 \times 0,2 \mathrm{~m}$, bractéolas menores, semelhantes a estas. Hipanto 0,4-0,8 x 0,4-0,5 cm, piloso-glanduloso. Lacínias 68 x 22,5 mm. Pétala 1,4-1,5 x 1,1-1,3 cm, roxa. Estames dimorfos; filetes glabros, conectivos bituberculados, filetes dos estames menores ca. $0,7 \mathrm{~cm}$ compr., tecas ca. 0,7 cm compr., conectivos curtamente prolongados; filetes dos estames maiores ca. $0,9 \mathrm{~cm}$ compr., tecas ca. 


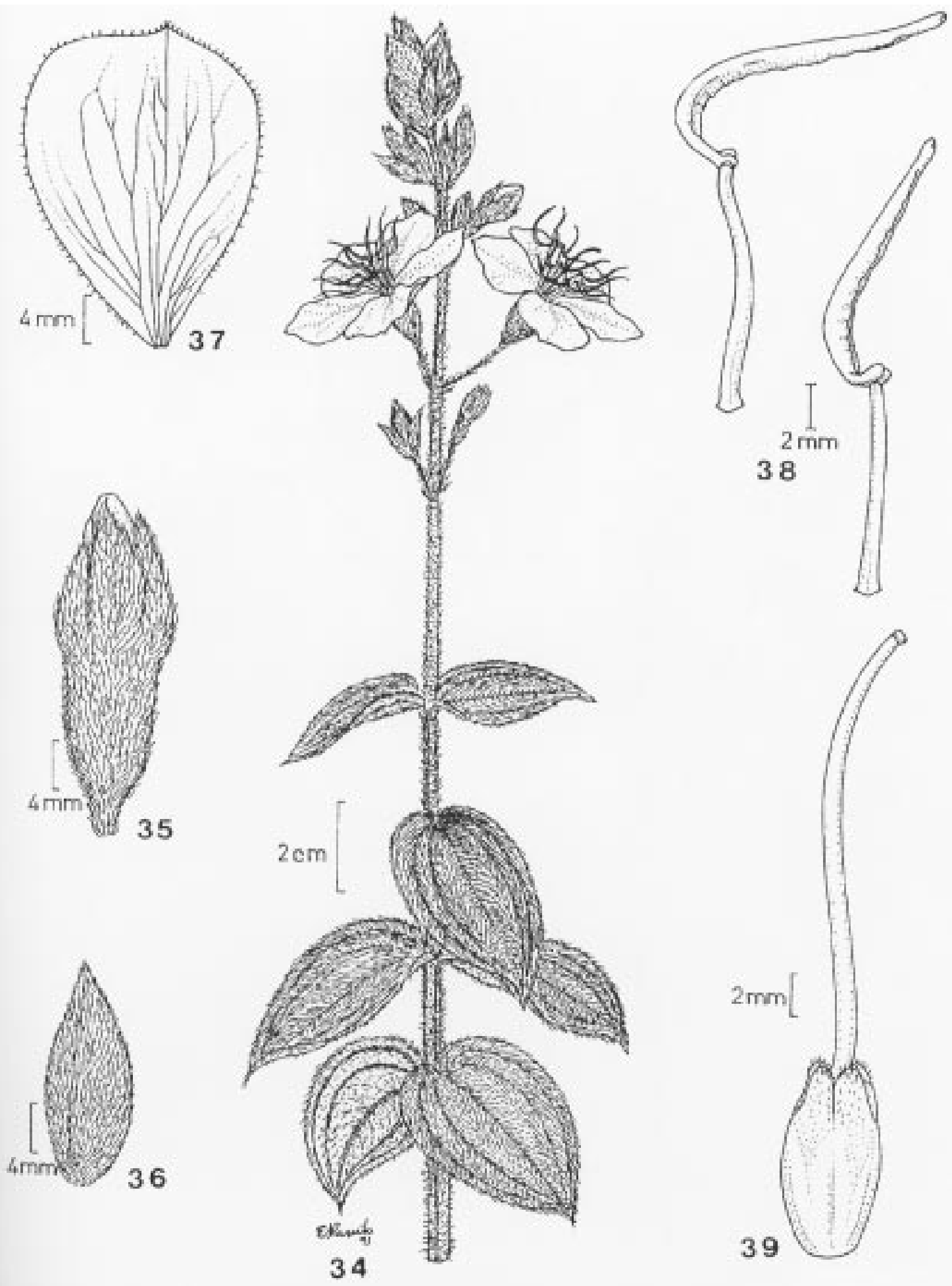

Figuras 34-39. Tibouchina ursina (Cham.) Cogn. (Brade 12.292). 34. Ramo; 35. Botão floral; 36. Bráctea; 37. Pétala; 38. Estames dos dois ciclos; 39. Gineceu. 

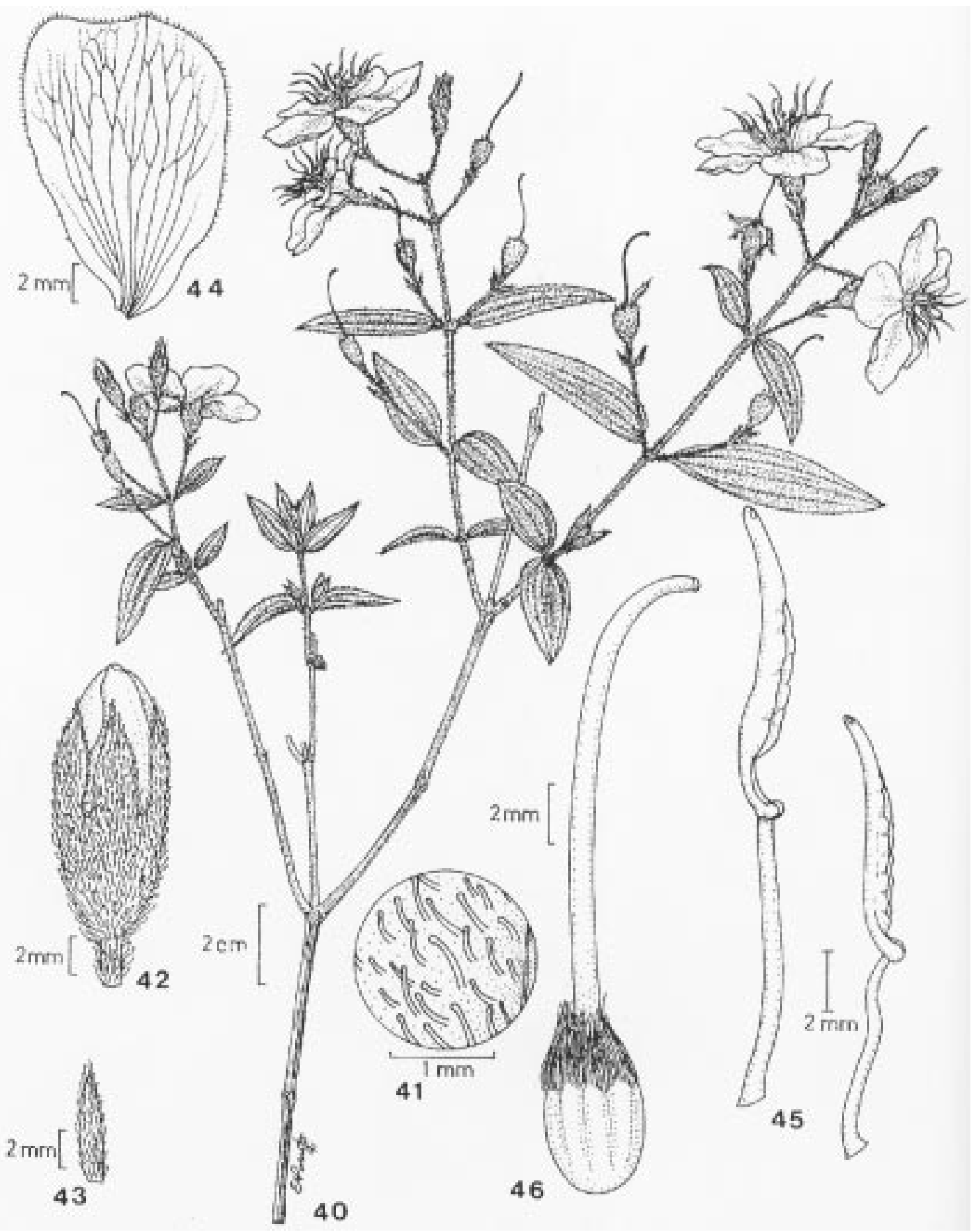

Figuras 40-46. Tibouchina chamissoana Cogn. (F.C. Hoenhne s.n. SPF 25.165). 40. Ramo; 41. Tricomas da face superior da folha; 42. Botão floral; 43 Bractéola; 44. Pétala; 45. Estames dos dois ciclos; 46. Gineceu. 
$0,7 \mathrm{~cm}$ compr., conectivos $2 \mathrm{~mm}$ prolongados. Ovário $0,5 \times 0,3 \mathrm{~cm}$, tricomas seríceos no ápice; estilete ca. 1,6 cm compr., glabro. Cápsula 0,8-0,9 x $0,5 \mathrm{~cm}$.
A cidade de São Paulo concentra um número maior de coletas de T. chamissoana, realizadas durante a primeira metade deste século principalmente em ambientes campestres, úmidos e

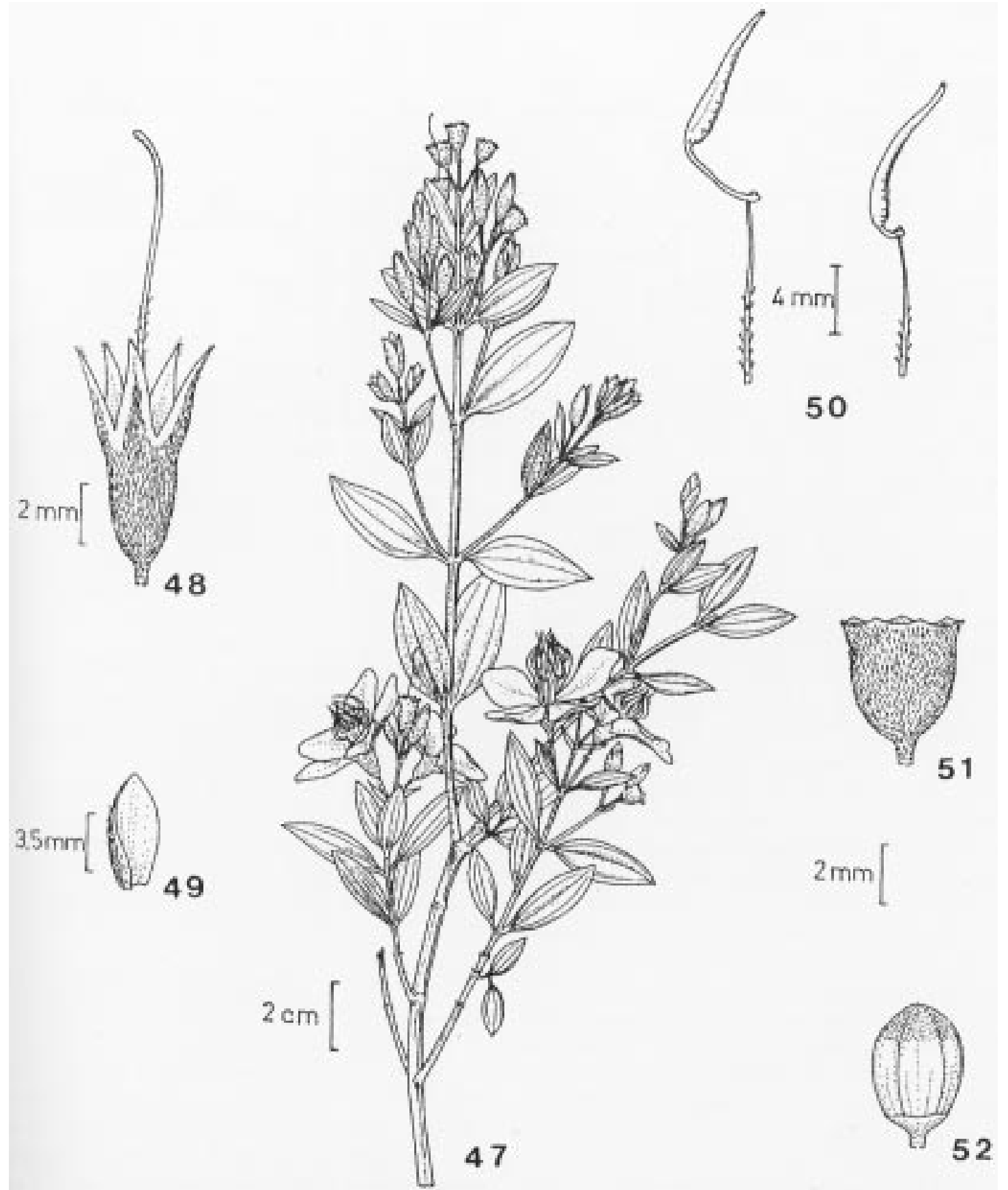

Figuras 47-52. Tibouchina riedeliana Cogn. (modificada de Cogniaux 1885). 47. Ramo; 48. Hipanto, lacínias e estilete; 49. Bráctea; 50. Estames dos dois ciclos; 51. Cápsula; 52. Ovário. 
brejosos. Coletas recentes em locais próximos da cidade de São Paulo, como Guarulhos e Pico do Jaraguá, registram ainda a presença desta espécie. Tibouchina chamissoana ocorre também nos estados do Paraná e de Minas Gerais.

Esta espécie pode ser reconhecida pela presença de tricomas glandulares revestindo a face superior da folha, nas nervuras na face inferior, nos ramos, hipanto e lacínias e pela ausência de tricomas nos filetes e no estilete.

Material Selecionado - Atibaia: set 1910 (fl), C. Duarte 251 (SP); Taubaté: 01 nov 1833 (fl), Lund 1032 (C); Pico do Jaragua: 25Km NW from São Paulo city, 29 set 1979 (fl), K. Mizoguchi 994 (MO); Caieiras: 28 set 1945 (fl, fr), W. Hoehne s.n. (SPF 13703, UEC); Guarulhos: bairro das Pimentas, sítio Kida 21 set 1980 (fl, fr), E. Forero et al. 8137 (SP); Itapetininga: Campo E 15 set 1887 (fl), A. Löfgren [CGGSP] 112 (C); São Paulo: av. Paulista, 05 nov 1909 (fl), Usteri 11 (SP); Ipiranga, 03 fev 1907 (fl), H. Luederwaldt s.n. (SP 14326); Vila Ema, nov 1914 (fl, fr), A.C. Brade 7428 (SP); Butantan, 04 jul 1917 (fl), F. C. Hoehne s.n. (SP 291, NY); Ipiranga, 19 out 1918 (fl, fr), F.C. Hoehne s.n. (SP 25165); Vila Ema, dez 1933 (fl, fr), A. C. Brade 12858 (RB); id., 15 out 1934 (fl, fr), W. Hoehne s.n. (SPF 10653, UEC); Santo Amaro, 15 out 1942 (fl, fr), L. Rotto s.n. (SP 50443); id., Jardim Botânico próximo ao abrigo e casa do guarda, 23 set 1958 (fl), M. Kuhlmann s.n. (SP 154556).

A cidade de São Paulo concentra um número maior de coletas de $T$. chamissoana, realizadas durante a primeira metade deste século principalmente em ambientes campestres, úmidos e brejosos. Coletas recentes em locais próximos da cidade de São Paulo, como Guarulhos e Pico do Jaraguá, registram ainda a presença desta espécie. Tibouchina chamissoana ocorre também nos estados do Paraná e de Minas Gerais.

Esta espécie pode ser reconhecida pela presença de tricomas glandulares revestindo a face superior da folha, nas nervuras na face inferior, nos ramos, hipanto e lacínias e pela ausência de tricomas nos filetes e no estilete.

8. Tibouchina riedeliana Cogn., in Mart., Fl. Bras. 14 (3): 368. 1885.

Figuras 47-52.
Arbusto 1,25-3 m alt. Folhas curtamente pecioladas, pecíolo $25 \mathrm{~mm}$ compr.; lâmina 2,5-3 x 0,9-1,3 cm, oblongo-lanceolada, base obtusa, ápice agudo, face superior adpresso-estrigosa, inferior esparso-serícea, nervuras 3-5. Flores reunidas em dicásios terminais ou axilares, ou flores isoladas axilares. Brácteas 6-8 x 3-5 mm. Hipanto 5-6 x 3-4 mm, escabro. Lacínias 4 x 2-3 mm. Pétalas 1,9-2 $\mathrm{x} 1,1 \mathrm{~cm}$, roxas. Estames dimorfos; filete com tricomas glandulares curtos, conectivo bituberculado, filetes dos estames menores $0,7-1 \mathrm{~cm}$ compr., tecas $0,7-0,9 \mathrm{~cm}$ compr., conectivo $1-2 \mathrm{~mm}$ prolongado; filetes dos estames maiores $1,1-1,3 \mathrm{~cm}$ compr., tecas $0,9-1,1 \mathrm{~cm}$ compr., conectivo $3,5-5 \mathrm{~mm}$ prolongado. Ovário $6 \times 5 \mathrm{~mm}$, densamente seríceo no ápice; estilete 1,8-2 cm, tricomas na porção inferior. Cápsula 5- 7 x 5-6 mm. Material Examinado - "prope" Mogi, nov. 1833 (fl), Riedel 1426 (BR, W; fotografia US, P, F).

Material Adicional Examinado - Paraná: Ponta Grossa: Fortaleza 13 dez. 1969 (fl, fr), G. Hatschbach 23220 (C, MO). Sem localidade precisa: s.d., (fl), sem coletor (US 1361606).

Tibouchina riedeliana está representada no estado de São Paulo por um único exemplar coletado "em mata perto de Mogi". Um outro exemplar desta espécie foi coletado no estado do Paraná, no município de Ponta Grossa. Neste material, os tricomas dos filetes são maiores e os conectivos menores do que os descritos por Cogniaux (1885) em $T$. riedeliana; nos demais caracteres confere com os sintipos e descrição da espécie.

Tibouchina riedeliana é relacionada com $T$. martialis pelo hábito, morfologia das folhas e pela inflorescência. Em T. riedeliana, as brácteas são consideravelmente maiores e os estames apresentam tricomas glandulares curtos na porção inferior dos filetes.

9. Tibouchina grandifolia Cogn., in Mart., Fl. Bras. 14 (3): 335. 1885.

Figuras 53-58.

Arbusto $1,7 \mathrm{~m}$ alt. Folhas longamente pecíoladas; pecíolo 3-6,6 cm compr.; lâmina $12,5-21 \times 8,5-15 \mathrm{~cm}$, cordado-ovada a cordiforme, base cordada, ápice obtuso, raramente agudo, margem inteira, face superior estrigoso-serícea, bulada, inferior foveolada, vilosa, nervuras 5 Panícula 30-39 cm compr., terminal. Brácteas 3-4 x 


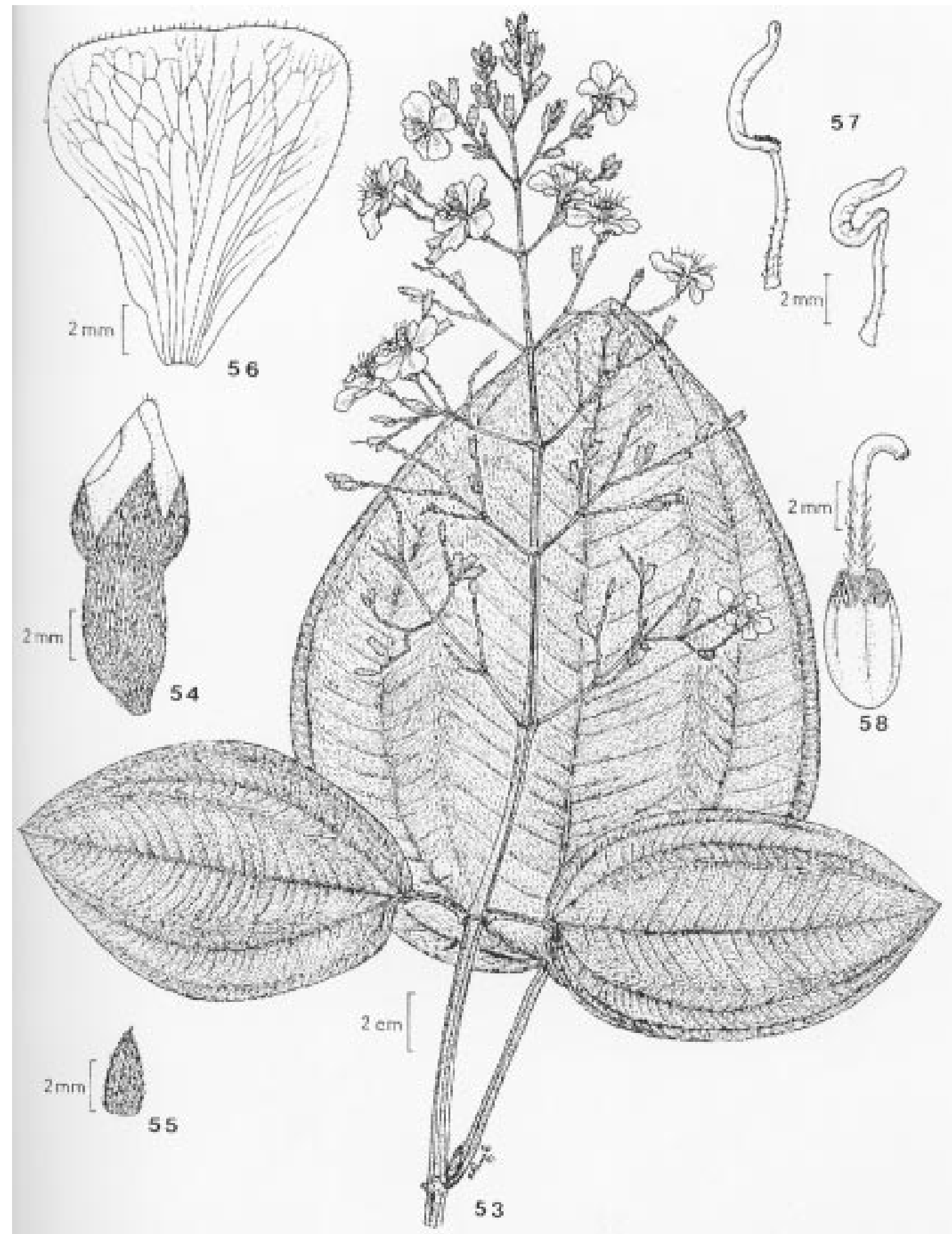

Figuras 53-58. Tibouchina grandifolia Cogn. (Frazão 10.775). 53. Ramo; 54. Botão floral; 55. Bractéola; 56. Pétala; 57. Estames dos dois ciclos; 58. Gineceu. 

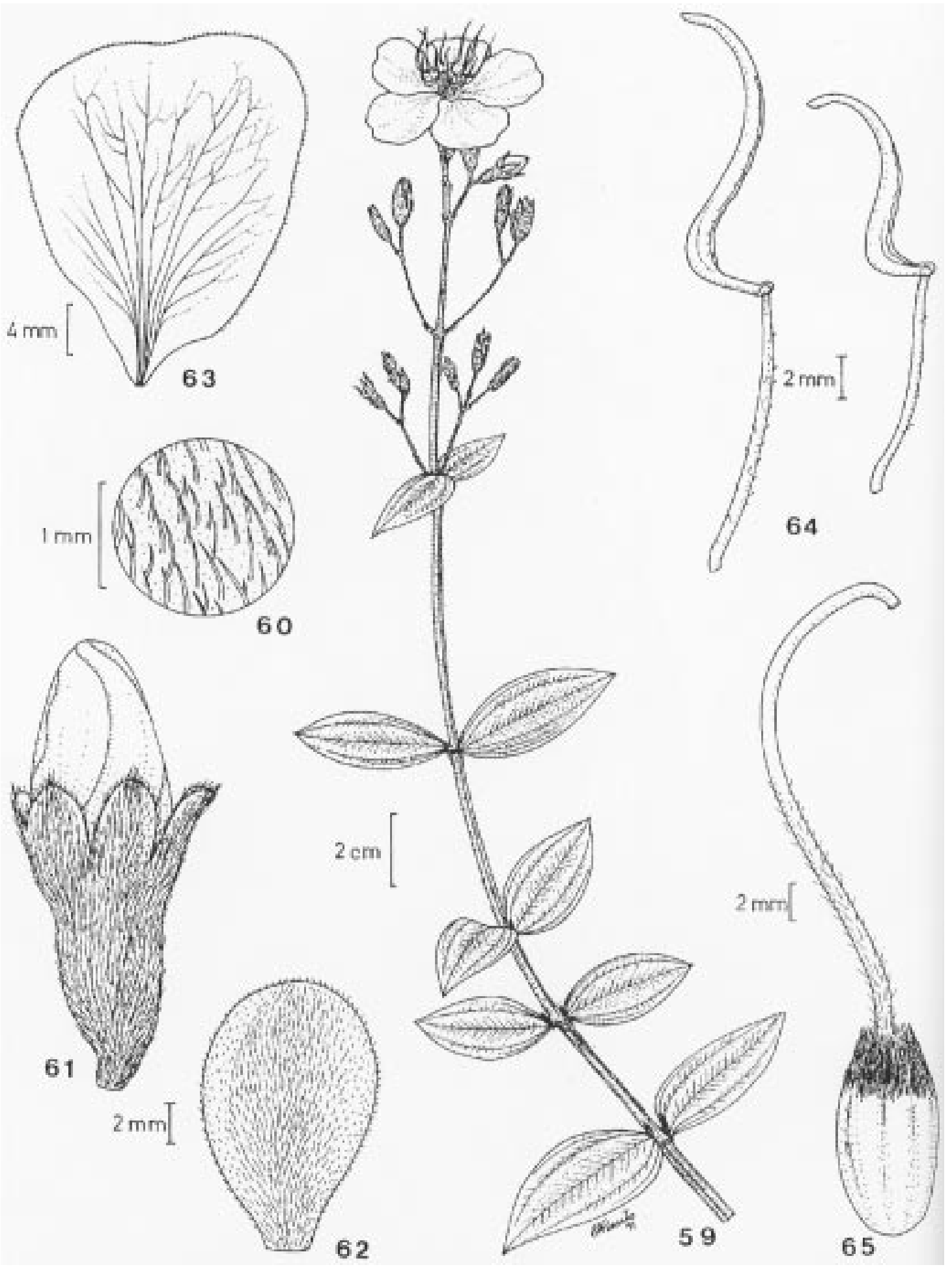

Figuras 59-65. Tibouchina urvilleana (DC.) Cogn. (J. Mattos 11.821). 59. Ramo; 60. Tricomas da face superior da folha; 61. Botão floral; 62. Bractéola; 63. Pétala; 64. Estames dos dois ciclos; 65. Gineceu. 


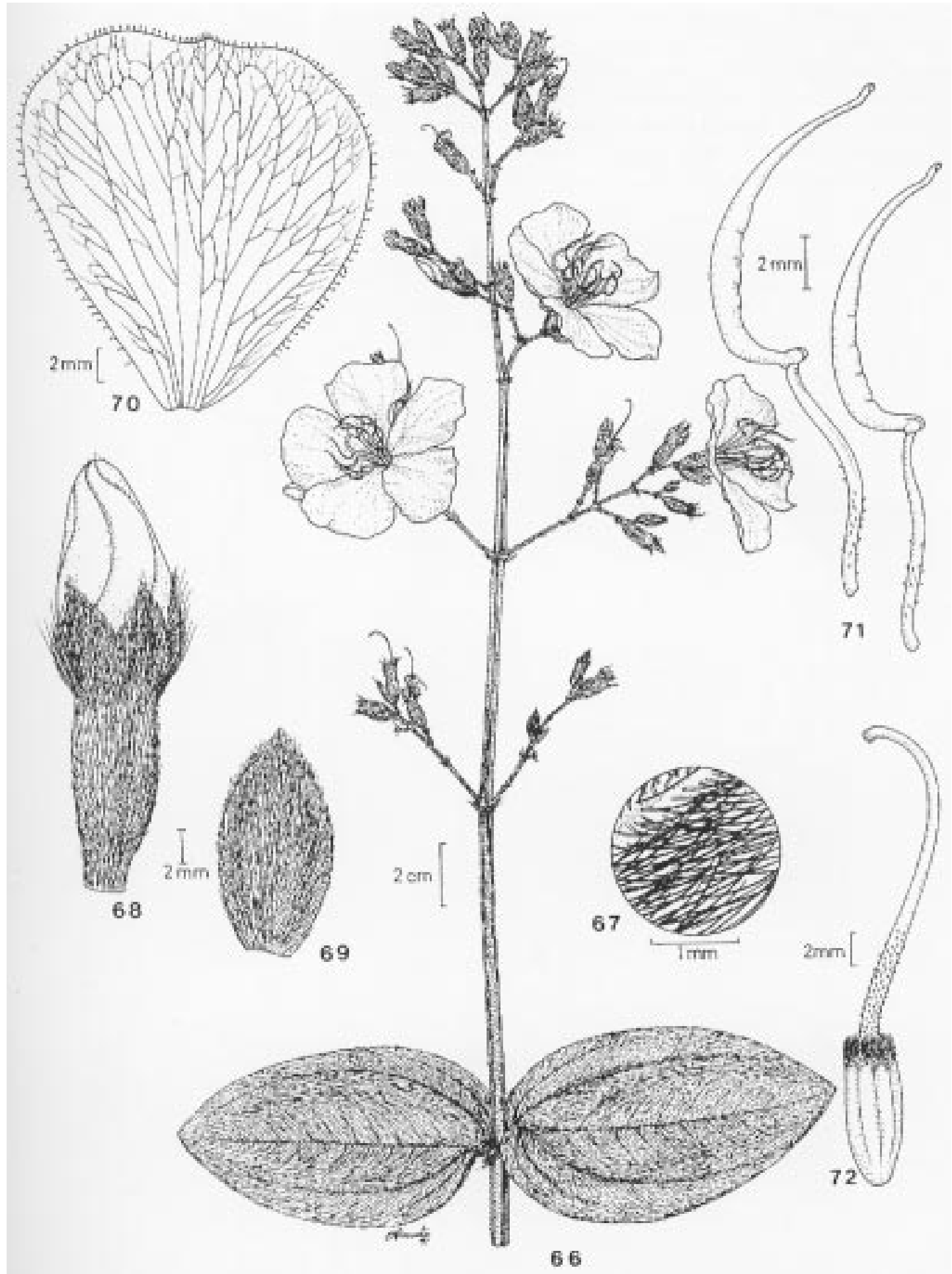

Figuras 66-72. Tibouchina clavata (Pers.) Wurd. (P. Guimarães 82). 66. Ramo; 67. Tricomas da face superior da folha; 68. Botão floral; 69. Bráctea; 70. Pétala; 71. Estames dos dois ciclos; 72. Gineceu. 
2-2,5 cm. Hipanto 4-5 x $3 \mathrm{~mm}$, seríceo. Lacínias 3 x $2 \mathrm{~mm}$. Pétalas $1,3 \times 1,2 \mathrm{~cm}$, roxas. Estames ligeiramente dimorfos; filetes com tricomas glandulares curtos na porção inferior, presentes também no conectivo, filetes dos estames menores ca. $4 \mathrm{~mm}$ compr., tecas 3,5-4 mm compr., conectivos 1-1,5 mm prolongados; filetes dos estames maiores ca.
5,5 mm compr., tecas ca. $5 \mathrm{~mm}$ compr., conectivos 1-1,5 $\mathrm{mm}$ prolongados. Ovário 4 x 2,5 $\mathrm{mm}$ tricomas seríceos no ápice; estilete ca. $5 \mathrm{~mm}$ compr., tricomas na porção inferior. Cápsula 0,8 x $0,4 \mathrm{~cm}$.

Material Selecionado - Campinas: 11 abr 1895 (f1), C. Novaes 3155 (SP); São Paulo: 1917 (f1), Frazão s.n.(RB 10775); id., Parque do Estado, 19 fev 1932

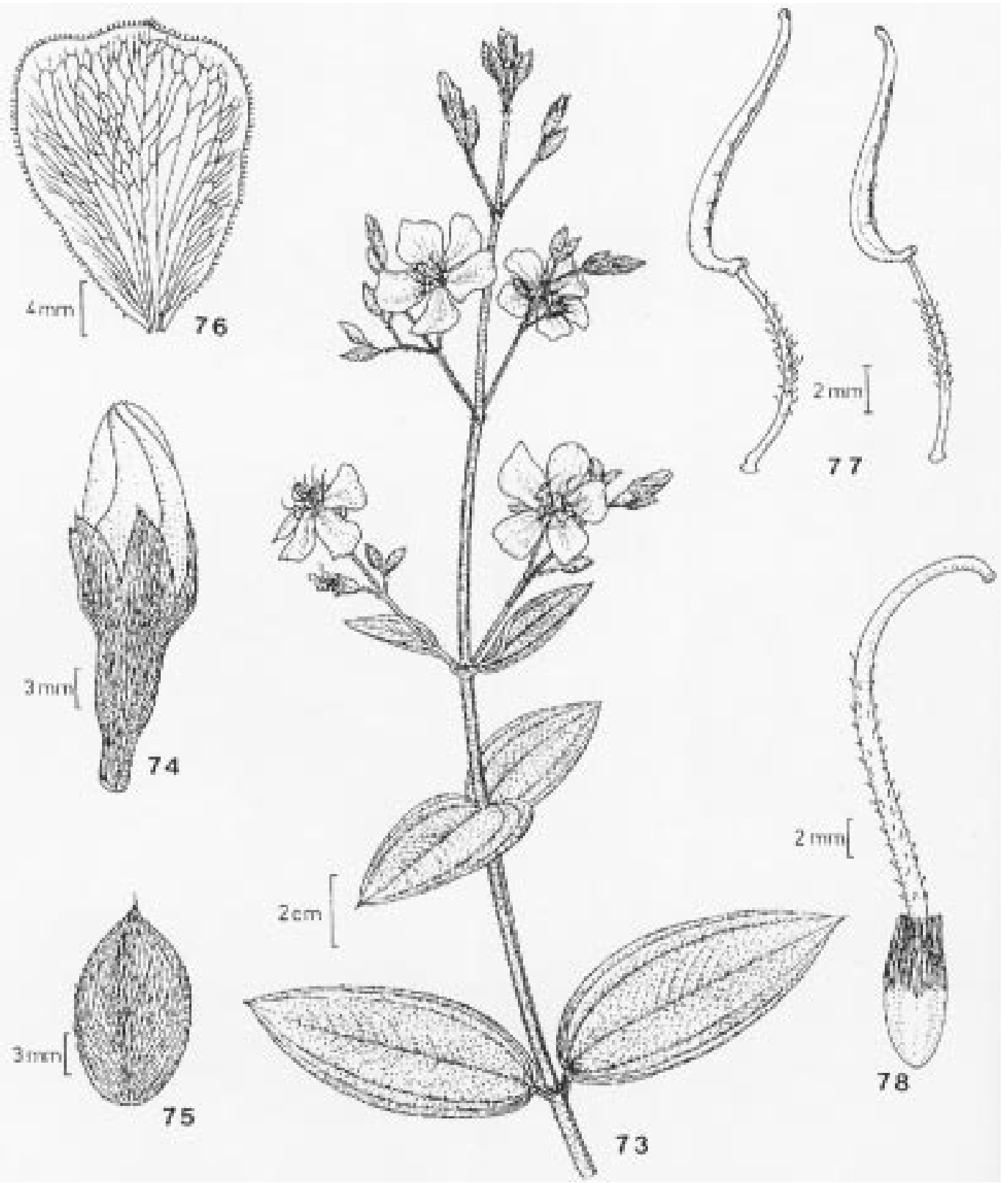

Figuras 73-78. Tibouchina langsdorffiana (Bonpl.) Baill. (Romero et al. 451) 73. Ramo; 74. Botão floral; 75. Bractéola; 76. Pétala; 77. Estames dos dois ciclos; 78. Gineceu. 
(fl, fr), F. C. Hoehne s.n. (NY, F 895845); id., 16 jul 1968 (fl), T. Sendulsky 993 (SP); id., 31 jan 1974 (fl), J. S. Silva 241 (SP); id., 8 fev 1979 (fl) A. Custódio Filho 14 (SP); id., Instituto Florestal de São Paulo, 30, mar 1984 (fl, fr), J. A. Pastore 8445 (UEC); id., s.d. (fl), F. C. Hoehne s.n. (SP 28796, NY); São José do Barreiro: 04 nov 1960 (fl, fr), O. Handro 913 (SP).

As poucas coletas de $T$. grandifolia no estado de São Paulo e a falta de informações nas etiquetas de herbário não nos permitiram delimitar a área e o ambiente de ocorrência desta espécie. Além do estado de São Paulo, sua ocorrência é também registrada para os estados do Rio de Janeiro e Espírito Santo (J. Semir, com. pess.).

Tibouchina grandifolia é um arbusto bastante ornamental cultivado em todo o estado.

$\mathrm{O}$ estreito relacionamento entre $T$. adenostemon (Schrank ex DC.) Cogn. , T. multiflora (Gardn.) Cogn., e $T$. grandifolia tem gerado discordâncias na identificação destas espécies. A separação entre elas, segundo Cogniaux (1885), é devida ao formato e tamanho das folhas e comprimento dos pecíolos. Acreditamos que observações de campo, realizadas nos estados de Minas Gerais e Rio de Janeiro, serão valiosas na sinonimização destas espécies.

10. Tibouchina urvilleana (DC.) Cogn., in Mart., Fl. Bras. 14 (3): 358. 1885.

Lasiandra urvilleana DC. in Prod. 3: 130. 1828. Figuras 59-65.

Arbusto a arvoreta de 1-4 m alt. Ramos obtuso-quadrangulares, não alados. Folhas pecioladas; pecíolo $0,4-0,5(1,1) \mathrm{cm}$ compr.; lâmina 5,5-7,2 x 2,6-3,3 cm, oblongo-lanceolada, base obtusa, ápice agudo a obtuso, margem inteira, serícea em ambas as faces, nervuras 57. Panícula 8-11 cm compr., terminal. Brácteas 1,4 x 0,8 cm. Hipanto 0,7-0,9 x 0,4 cm, seríceo. Lacínias 0,5 x $0,3 \mathrm{~cm}$. Pétalas 2,5-2,7 x 2,2 cm, roxo-avermelhadas. Estames dimorfos; filetes subglabros ou com tricomas glandulares na porção inferior, conectivos bituberculados, filetes dos estames menores ca. $1,1 \mathrm{~cm}$ compr., tecas ca. $1 \mathrm{~cm}$ compr., conectivos $0,1 \mathrm{~cm}$ prolongados; filetes dos estames maiores $1,3-1,4 \mathrm{~cm}$ compr., tecas 1,2-1,3 cm compr., conectivos 0,2-0,4 cm prolongados. Ovário 8,5 x 4,5 mm, tricomas seríceos no ápice; estilete ca. 2,3 cm compr., tricomas seríceos na porção inferior. Cápsula 1 x 0,6 cm.
Material Selecionado - Santos: margem da rodovia Anchieta, 03 set 1958 (fl, fr) M. Kuhlmann 4448 (SP); São Paulo: Jardim Botânico; mai 1958 (fl) M. Kuhlmann 4398 (SP); São Vicente: Praia Grande, 11 jan 1964 E. Pereira 8157 (RB); Em município não indicado: Pedro Taques. rodovia Cubatão-Mongagua mar 1964 (fl), J. Mattos 11821 e 11830 (SP).

Tibouchina urvilleana foi coletada neste estado no litoral, ocorrendo também no Paraná, Rio de Janeiro (Cogniaux 1885), Rio Grande do Sul e Santa Catarina.

Os caracteres distintivos de T. urvilleana, conectivo longamente prolongado abaixo das tecas nos estames maiores e folhas revestidas por indumento denso-seríceo, não estão evidentes nos materiais coletados no estado de São Paulo.

Comparamos os materiais aqui relacionados com exemplares de $T$. urvilleana identificados por Wurdack, coletados próximo à divisa do estado de São Paulo, com os quais encontramos uma maior identidade. Com base nestas informações, podemos reconhecer os espécimes aqui coletados como pertencendo a T. urvilleana.

11. Tibouchina clavata (Pers.) Wurdack, Phytologia 7: 233. 1960.

Melastoma clavata Pers., Syn. Plant. 1: 476. 1805.

Tibouchina holosericea (Sw. ) Baill. Hist. des Pl. 7:34. 1877.

Figuras 66-72.

Arbusto 0,3-3 m alt. Ramos quadrangulares, não alados. Folhas quase sésseis, lâmina 6-10 x 3,5-6,4 cm, cordado-ovada a cordado-oblonga, base cordada, ápice obtuso, arredondado ou agudo, margem inteira, face superior serícea, inferior viloso-serícea, nervuras 5. Panícula 15-39 cm compr., terminal. Brácteas 1-1,2 x 0,6-0,8 cm. Hipanto 1-1,5 x 0,3-0,5 cm, seríceo. Lacínias 0,5-0,7 x 0,3 cm. Pétalas 2,1-2,3 x 22,1 cm, roxas, lilazes, raramente brancas. Estames pouco dimorfos; filetes com tricomas glandulares curtos na porção inferior, conectivos curtamente bituberculados; filetes dos estames menores 0,9-1 cm compr., tecas 0,9-1,1 cm compr., conectivos $0,9 \mathrm{~mm}$ prolongados; filetes dos estames maiores 1-1,1 cm compr., tecas ca. $1,2 \mathrm{~cm}$ compr., conectivos 1,2-1,9 $\mathrm{mm}$ prolongados. Ovário 0,6 x 0,3 cm, com tricomas 
seríceos no ápice; estilete ca. 2,5 cm compr., tricomas glandulares curtos na porção inferior. Cápsula 1-1,2 x 0,5-0,6 cm.

Material Selecionado - Campo Grande: Estação Biológica, 234' S 46²0’W, 23 fev 1929 (fl, fr), C. B. Smith 1979 (NY); Cananéia: ca. 15 km. N of Cananéia, 2453'S 4758'W, 13 out 1986 (fl), G. L. Webster et al. 25540 (SP); Caraguatatuba: 11 jun 1938 (fl), J. E. Rombouts s.n. (SP 40927); Conceição de Itanhaen: $24^{\circ} 11^{\prime} \mathrm{S} 46^{\circ} 47^{\prime} \mathrm{W}, 05$ mar 1929 (fl, fr), L. B. Smith 2070 (NY); Guarujá: praia do Pernambuco, 06 fev 1946 (fr), Burle Mark \& Mello Barreto 15361 (RB); Iguape: Pariquere-Açú, jan 1911 (fl, fr), A. C. Brade 6078 (SP); Ilha de Santo Amaro: between $\mathrm{Km} 18$ and 19 on highway from Guarujá to Bertioga n.e. Santos, 20 dez 1964 (fr), F. R. Fosberg 45970 (US); Ilha do Cardoso: opposite Cananéia, 07 set 1976 (fl), P. H. Davis et al. 60610 (UEC); Ilha dos Alcatrazes: out 1920 (fl), H. Luderwaldt \& J. P. Fonseca s.n. (SP 14327); Mongagua: Praia Grande, 21 jan 1951 (fl), W. Hoehne s.n. (UEC); Peruibe: 30 out 1891 (fl), Löfgren \& Edwall [CGGSP] 1634 (SP, C); São Sebastião: estrada Rio-Santos a $15 \mathrm{Km}$ da cidade no sentido a Bertioga 06 out 1979 (fl), G. Shepherd et al. 10454 (UEC); São Vicente: $15 \mathrm{Km}$ east of Mongaguá on main highway, 03 mar 1967 (fl), G. Eiten \& L. T. Eiten 8042A (SP, UB); Ubatuba: Estação Experimental, 25 nov 1938 (fl), A. S. Costa \& I. Ramos s.n. (IAC 4361); Picinguaba, 06 dez 1990 (fl), P. Guimarães 82 (UEC); Piringuaba, trilha do Picadão da Barra, 13 mar 1992 (fl), R. Romero 461 (UEC).

Esta espécie estava identificada na maioria dos herbários como Tibouchina holosericea Baill. Este táxon teve seu epíteto alterado para T. clavata por Wurdack (1960).

Tibouchina clavata é bastante freqüente no estado de São Paulo, na restinga, nas baixadas úmidas entre as dunas e nas zonas marginais onde há vegetação arbustiva. Esta espécie foi também coletada em Santa Catarina (Wurdack 1962 ), Paraná e Rio de Janeiro.

Esta espécie pode ser reconhecida pela pilosidade serícea que reveste densamente folhas (figura 67), hipanto, lacínias e brácteas externamente, pelas folhas subsésseis e conectivo glabro.

Tibouchina clavata é relacionada com $T$. adenostemon (Schrank ex DC.) Cogn. pela pilosidade serícea que reveste as folhas e outras partes da planta, porém a presença de tricomas glandulares no conectivo de T. adenostemon, separa bem estas duas espécies, além de uma distribuição bastante distinta. T. adenostemon ocorre em localidades de altitude elevada, no interior do país, principalmente no estado de Minas Gerais.

12. Tibouchina langsdorffiana (Bonpl.) Baill. in Hist. des Pl. 7: 34. 1879

Rhexia langsdorffiana Bonpl., Rhex. 135. 1823

Figuras 73-78.

Arbusto até $3 \mathrm{~m}$ alt. Ramos quadrangulares, subalados. Folhas pecioladas; pecíolo 0,6-lcm compr.; lâmina 7,8-12,5 x 3,1-5,3 cm compr., oblongolanceolada, base cordada, ápice obtuso ou agudo, margem inteira, serícea nas duas faces, nervuras 5-7. Inflorescência em panícula 9-25,5cm compr., terminal. Brácteas 1,4-1,8 x 0,9-1 cm; bractéolas semelhantes, um pouco menores. Hipanto 7-9 x $4 \mathrm{~mm}$, seríceo. Lacínias 6-7 x 3-4mm. Pétalas 2,1-2,3 x 1,4-1,6 cm, roxas. Estames subisomorfos; filetes com tricomas glandulares curtos, conectivo bituberculado, filetes dos estames menores com $0,9 \mathrm{~cm}$ compr., tecas $1 \mathrm{~cm}$ compr. conectivo $0,6 \mathrm{~mm}$ prolongado; filetes dos estames maiores $1 \mathrm{~cm}$ compr., tecas ca. $1,1 \mathrm{~cm}$ compr. conectivo 1-1,5 mm prolongado. Ovário 7 x $3 \mathrm{~mm}$, densamente seríceo no ápice; estilete ca. $2,4 \mathrm{~cm}$ compr. com tricomas na porção inferior ou subglabro. Cápsula não vista.

Material selecionado - Ubatuba: Picinguaba, trilha do Picadão da Barra, 26 nov 1991 (fl), R. Romero et al. 404 (UEC); id., Picinguaba, trilha do Picadão da Barra, Três Lagoas 29 dez 1991 (fl), R. Romero et al. 451 (UEC).

No estado de São Paulo, T. langsdorffiana foi coletada apenas no município de Ubatuba, em vegetação litorânea. Ocorre também no município do Rio de Janeiro, onde foi registrada por coletas antigas realizadas entre 1820 e 1886.

Esta espécie pode ser reconhecida pela presença de lacínias longas, de comprimento igual ou superior ao hipanto, folhas com pecíolo curto e ramos agudo quadrangulares, subalados.

Tribouchina langsdorffiana é relacionada com os exemplares de T. urvilleana coletados em São Paulo pelo indumento das folhas e pilosidade dos filetes e estilete. As diferenças residem, principalmente, no tamanho das folhas, menor em T. urvilleana, não 
tendo sido encontrados indivíduos intermediários, e por esta espécie apresentar ramos não alados, obtuso-quadrangulares. T. langsdorffiana é próxima também de $T$. clavata, diferindo no formato das folhas e comprimento do pecíolo.

Agradecimentos - A realização deste trabalho foi possível graças ao auxílio financeiro fornecido pela CAPES, à paciente colaboração dos curadores e pessoal técnico dos herbários $\mathrm{C}, \mathrm{F}$, HRCB, IAC, K, MO, NY, P, RB, SP, SPF, UB, UEC, US, a Sra Emiko Naruto que confeccionou as ilustrações e sobretudo, ao incentivo de pessoas aqui não citadas, porém às quais os autores muito devem.

\section{Referências bibliográficas}

BAUMGRATZ, J. F. A. 1982. Miconias do Estado do Rio de Janeiro. Seção Tamonea (Aubl.) Cogniaux (Melastomataceae). Archos Jard. bot., Rio de Janeiro. 26: 69-86.

BAUMGRATZ, J. F. A. 1894. Miconias do Estado do Rio de Janeiro. Seção Chaenanthera Naud. (Melastomateceae) Rodriguésia 36: 45-58

BAUMGRATZ, J. F. A. 1987. Revisão taxonômica do gênero Bertolonia Raddi. Tese de mestrado, Universidade Federal do Rio de Janeiro, Rio de Janeiro.

COGNIAUX, A. 1885 Melastomataceae. Tribus II. Tibouchineae. Flora brasiliensis. v. 14, partes 3. Frid. (C.F.P, Martins \& A.G. Gichler, eds.). Fleischer, Lipsiae.

COGNIAUX, A. 1891. Melastomataceae. Monographiae phanerogamarum, 7: 1-1256. (A. de Candolle \& C. de Candolle, eds.). G. Masson, Paris.

HARLEY, R. M \& S. J. MAYO. 1980. Towards a checklist of the flora of Bahia, Brazil. Royal Botanic Gardens, Kew.

MARTINS A.B. 1984. Revisão taxonômica do gênero Cambessedesia DC. (Melastomataceae). Tese de mestrado, Universidade Estadual de Campinas, Campinas.

MARTINS A.B. 1989. Revisão taxonômica do gênero Marcetia DC. (Melastomataceae). Tese de doutorado, Universidade Estadual de Campinas, Campinas.
MARTINS, E. 1991. A tribo Microlicieae (Melastomataceae) no Estado de São Paulo. Tese de mestrado, Universidade Estadual de Campinas, Campinas.

MATHIES, P. S. 1981. A revision of Aciotis (Melastomataceae). Thesis, Mississippi State University.

PEREIRA, E. 1960. Flora do Estado da Guanabara. III. Melastomataceae I. Tibouchineae. Rodriguésia, 23/24: 155-172.

PEREIRA, E 1962. Flora do Estado da Guanabara. VI. Melastomataceae II. Miconieae, gênero Miconia. Archos. Jard. bot., Rio de Janeiro. 18: 183-214.

PEREIRA, E. 1966. Flora do Estado da Guanabara. V. Melastomataceae. Tribos Miconieae, Merianieae, Bertolonieae e Microlicieae. Rodriguésia, 25: 181-202.

RAMBO, B. 1958. Geografia das Melastomatáceas riograndensis. Sellowia, 10: 147-167.

RAMBO, B. 1966. Melastomatáceas riograndensis. Pesquisas, Bot. 22:148

RENNER, S.S. 1989 a. A survey of reproductive biology in neotropical Melastomataceae \& Memecylaceae. Ann. Mo. bot. Gdn, 76:496-518.

RENNER, S.S. 1989 b. Systematic studies in the Melastomataceae. Bellucia, Loreya and Macairea. Mem. New York Bot. Gard. 50:1-112.

RENNER, S.S. 1990. A revision of Rhynchanthera (Melastomataceae). Nord. J. Bot., 9:601-630.

RENNER, S. S. 1994 a. Revisions of Pterogastra and Schwackaea (Melastomataceae: Melastomae) Nord. J. Bot. 14:65-71

RENNER, S.S. 1994 b. A revision of Pterolepis (Melastomataceae: Melastomaeae) Nord. J. Bot. 14:73-104.

SOUZA, M. L. D. R. 1989. A taxonomic study of genus Tibouchina Aubl. (Melastomataceae) in Rio Grande do Sul, Brazil. Insula. Florianópolis. 16:3-109.

TODZIA, C. A. \& F. ALMEDA. 1991. A revision of Tibouchina section Lepidotae (Melastomataceae: Tibouchineae). Proc. Cal. Acad. Science 47:175-206.

WURDACK, J.J. 1960. Certamen Melastomataceis VI. Phytologia 7:233.

WURDACK, J.J. 1962. Melastomataceae of Santa Catarina. Sellowia, 14:109-217. 